\title{
Commercial Law Collides with Cyberspace: The Trouble with Perfection - Insecurity Interests in the New Corporate Asset
}

\author{
Xuan-Thao N. Nguyen
}

The recent downturn in the economy, particularly in the e-commerce sector, reveals many e-companies heading toward bankruptcy with cyberassets, such as domain names, as their most valuable corporate assets. Lending institutions and other creditors that have extended loans to such e-companies obviously want to get their hands on these bankrupt estates. Which creditor will have priority in the new cybercollateral of domain names? The answer to creditor priority questions may depend on whether domain names are intangible property for purposes of secured transactions. If so, should security interests in domain names be perfected under the Uniform Commercial Code or under federal law? This Article asserts that domain names are a form of intangible property, and that although they are not subject to the tort of conversion, they can be used as collateral in secured transactions. This Article proposes and evaluates two perfection schemes for security interests in domain names. The first proposal follows the existing state-regulated scheme through which creditors perfect their security interests in domain names by filing a financing statement with the applicable state filing office. The second proposal is a federal-based scheme through which creditors perfect their security interests in domain names by electronically filing a financing statement with a domain name registrar who will record the security interest information within the WHOIS database.

- Associate Professor of Law, Texas Wesleyan University School of Law; J.D. 1995, Northeastem University School of Law, B.A. 1990, Oberlin College. Intellectual Property Associate, Fried, Frank, Harris, Shriver \& Jacobson (New York City); Intellectual Property Associate, Pryor, Cashman, Sherman \& Flynn, LLP (New York City). Thanks to my colleague, Professor Jeff Maine, for a good competition. Thanks to Lora A. Moffatt, Partner, Intellectual Property Practice, Salans Hertzfeld Heilbronn Christy \& Viener of New York City for her enthusiasm for this topic and for desiring a reprint as soon as possible. Special thanks to my soul mate Erik Darwin Hille and our son Khai-Leif Nguyen-Hilie for their love, kindness, and support. $O 2001$ by Xuan-Thao N. Nguyen. 


\section{Table of Contents}

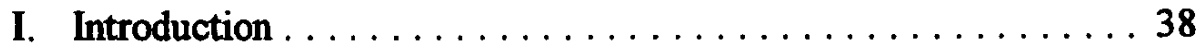

II. Perfection and Federal Preemption . . . . . . . . . 43

III. Perfection of Security Interests in Trademarks . . . . . . . . 48

IV. Domain Names as General Intangibles . . . . . . . . . . . 57

A. Domain Names as the New Valuable Corporate Assets . . . 57

B. Domain Names Valuation . . . . . . . . . . . 59

C. Domain Names and Property Interests . . . . . . . . . 62

1. Domain Name Formation . . . . . . . . . . . . 62

2. Domain Names: Contractual Rights or Intangible Property? . . . . . . . . . . . . . . . . . . . . 64

3. Domain Names and the Relevant Federal Statute . . . . 72

V. Securing Interest in Domain Names . . . . . . . . . . . . 74

A. Perfection Through Filing with the State . . . . . . . . 74

B. Perfection Through Filing with the Registrar of Domain

Names . . . . . . . . . . . . . . . . . . 78

VI. Conclusion $\ldots \ldots \ldots \ldots \ldots \ldots \ldots \ldots \ldots \ldots \ldots \ldots \ldots \ldots$

\section{Introduction}

Picture this scenario: As counsel for several venture capital firms in the New Economy, you had been enjoying the ride of the explosive growth of e-commerce in the last few years. You have assisted your venture capital (VC) clients in funding their ventures in e-companies whose primary cyberassets are domain names such as sex.com, business.com, loans.com, jewelry.com, and stock.com. E-companies have bought business.com for $\$ 7.5$ million, ${ }^{1}$ jewelry.com for $\$ 5$ million, ${ }^{2}$ and loans.com for $\$ 3$ million. $^{3}$ Others have estimated that sex.com is worth $\$ 250$ million $^{4}$ and that stock.com is

1. See Greg Johnson, The Costly Game for Net Names, L.A. Times, Apr. 10, 2000, at A1 (reporting purchase of domain name business.com for $\$ 7.5$ million in stock and cash).

2. See Silvis Sansoni, It Was Good While It Lasted: Internet Hotshots Reflect on Where All the Money Went, FoRBES, Dec. 25, 2000, at 36 (reporting that Richard Caniglia, V.P. of Operations for Miadora.com and online jewelry retailer for Online Jewelry, recalled that his company "bought a company that was little more than a URL - Jewelry.com - for \$5 million").

3. See Cynthia Flash, Are They Cybersquatters or Cyberentrepreneurs?, CMP TECHWEB, July 20, 2000, available at 2000 WL 2667397 (reporting that loans.com was sold to Bank of America for $\$ 3$ million, that beautiful.com is on sale at $\$ 3$ million, and that flu.com is on market for $\$ 1.4$ million).

4. Martin Kady, Sex.com Fight Rages: Lots of Money at Stake in Valuable Web Name, SAN JOSE AND SUICON VALLEY BUS. J., Aug. 18, 2000, at 3 (noting that domain name sex.com 
worth $\$ 7.5$ million. ${ }^{5}$ Trademark law does not protect these domain names because they are generic terms. ${ }^{6}$ Nevertheless, as indicated by the prices paid, these generic domain names are highly valuable commodities that are sought after in the New Economy.?

Lately, the slowdown of the economy and the continuous adjustment of the stock market are causing your clients some discomfort. ${ }^{8}$ Your VC clients' investments in e-companies are not performing well, and investors are not pouring currency into incubation projects as they once did. ${ }^{9}$ Many financing

is reportedly worth \$250 million); Jon Swartz, Sex.com Ownership Ruling Expected, Domain Name Hotly Disputed, USA TODAY, Aug. 2, 2000, at 3B (stating that domain name sex.com is estimated to be worth around \$250 million). Sex.com was estimated during litigation to be worth $\$ 250$ million. See http://www.submerged-ideas.com/valuation/topdomainsales.htm (last visited Feb. 15, 2002) (noting valuation of sex.com).

5. See Simon Brooke, Be Master of Your Own Domain, The DaIly TelzarapH, Mar. 15,2001 , at 70, available at 2001 WL 15593636 (reporting that stock.com is available for sale at \$7.5 million); Nick Wingfield, The Game of the Name, WALL ST. J., Nov. 22, 1999, at R14 (reporting that bingo.com sold for $\$ 1.1$ million, drugs.com sold for $\$ 823,456$, and university.com sold for $\$ 530,000)$.

6. See Kremen v. Cohen, 99 F. Supp. 2d 1168, 1174 (N.D. Cal. 2000) (noting that dormant domain names are unprotected by trademark law); see also Xuan-Thao N. Nguyen, Shifting the Paradigm in E-Commerce: Move Over Inherently Distinctive Trademarks, The Ebrand, I-brand and Generic Domain Names Ascending to Power?, 50 AM. U. L. REv. 937, 96566 (2001) (arguing that generic domain names are not entitled to trademark protection).

7. Dorer v. Arel, 60 F. Supp. 2d 558, 561 (E.D. Va. 1999) (noting that generic domain names have significant market value).

8. See, e.g., Chris Gaither, Intel Plans Broad Measures to Cut Costs, N.Y. TMEs, Feb. 21,2001 , at C6 (stating that "Intel joins the growing list of technology companies tightening their belts as their business markets, booming only a year ago, grow increasingly uncertain"); Saul Hansell, Some Hard Lessons for Online Grocer, N.Y. Times, Feb. 19, 2001, at C1 (explaining that online grocer Webvan has spent \$1 billion struggling to survive and that investors are unwilling to invest additional money until Webvan obtains profitability); Saul Hansell, Yahoo Warms on Sales, and Its Chief Resigns, N.Y. TIMES, Mar. 8, 2001, at C1 (reporting that market for Internet advertising is disappearing, sending Yahoo's sales to their lowest level since end of 1999); Jennifer S. Lee, Discarded Dreams of Dot-Com Rejects, N.Y. TIMES, Feb. 21, 2001, at Cl (reporting wave of dot-com layoffs); Floyd Norris, What Were Once Ladders Are Now Chutes: A Return to Earth for the Stock Class of 2000, N.Y. TMISS, Mar. 8, 2001, at C1 (noting that shares of seventy-seven IPO's debuting from January 31 to March 10, 2000, were valued at $\$ 25.9$ billion combined as of March 10, 2000, but were worth only $\$ 5.3$ billion as of March 7, 2001).

9. See Sansoni, supra note 2, at 36 (interviewing chief executive for internet software company who noted that his company had recently "produced two products that were loved by potential clients but not loved by investors ... [T]nvestors would say: 'Call me when the Nasdaq gets over 4500.'"). Sansoni also interviewed Richard Fuller, founder of PropertyOps.com, an online services for property managers that lasted for nine months. Id. Fuller recalled that the site had been active for just six weeks when it ran out of cash. PropertyOps failed because we raised only $\$ 750,000$ - had we raised $\$ 2.5$ million we would be profitable today. The heartbreaking thing was the wealth dried up. Every time 
projects that you have started on behalf of your clients are now on the back burner.

Your office telephone is ringing, and you quickly glance at the caller ID display. It is a call from one of your VC clients. The client asks: "Will we have a chance to salvage any of the cyberassets? Who will get the domain names? What will happen to the proceeds of the sale of the cyberassets in the event that some of the e-companies are heading toward bankruptcy?" You do not have any answers, but you promise your client that you will look into the matter further.

You search your gray cells. You recall that most, if not all, the e-deals were equity-based investments, not secured transactions as in the Old Economy. You are sweating a little bit because you honestly do not know whether your client had a security interest in the domain names and whether such security interest even was perfected. You rush to the library and look up a treatise on secured transactions. Words like "personal property,"10 "attachment,"11

we had a term sheet and a handshake, the market would drop 400 points and investors would pull out.

Id. Similarly, Michael Shields, founder of OnlineOffice.com, recalled in his interview with Sansoni:

I was trying to raise money in April. I had back-to-back meetings scheduled with investment bankers, and if the Nasdaq was down, only a junior guy would show up; when it bounced back, the top level people would attend. Things changed by the hour. At 9 a.m. they wanted to invest. By 3 they weren't doing any more dotcoms.

Id.

10. Personal property that can be used as collateral for secured transactions under the revised Article 9 of the Uniform Commercial Code includes goods, documents of title, instruments (such as promissory notes), chattel paper, investment property (such as securities entitlements, securities accounts, commodity contracts, and commodity accounts), crops, fixtures, accounts, deposit accounts, payment intangibles, and general intangibles (such as copyrights, patents, trademarks, and associated goodwill). See U.C.C. \$ 9-102 (2001) (setting out definitions of various personal property used as collateral); U.C.C. \$ 9-109(a) (2001) (providing scope of Article 9). All citations are to the recently revised Article 9 of the Uniform Commercial Code, unless indicated otherwise.

11. Attachment is the process by which the security interest in favor of the creditor becomes effective against the debtor. See U.C.C. \& 9-203(a) (2001) (describing attachment process). The security interest is attached to collateral when the following steps are met:

1. A security agreement (the contract between the creditor and the debtor wherein the debtor grants the creditor security interests in the collateral) must be authenticated by the debtor,

2. The security agreement must provide a description of the collateral;

3. The creditor must give value (usually a loan or credit) to the debtor, and

4. The debtor must have rights in the collateral or the power to transfer rights in the collateral to the creditor.

See U.C.C. § 9-203(a) \& (b) (2001) (listing necessary preconditions to enforcement of security interest). 
"perfection,"12 "financing statement,"13 and "collateral"14 leap out at you. You wonder whether domain names are personal property for the purposes of secured transactions under state commercial law statutes. You are sweating a little bit more.

The above scenario highlights some of the new problems concerning secured transactions in e-commerce and how the characteristics of e-commerce alter the traditional valuation of corporate assets. ${ }^{15}$ Indeed, in the New Economy the normative tangible form of assets such as corporate headquarters, branch offices, warehouses, land, equipment, and inventories are not the assets typically owned by Internet companies. ${ }^{16}$ Instead, due to the cyberspace nature of these companies, most of their value consists of intangible assets that include domain names, trademarks, patents, patent applications, copyrights, and proprietary information. ${ }^{17}$ The recent downturn of the e-commerce

12. Perfection is the process by which the creditor's security interest becomes effective against other creditors, lien holders, and bankruptcy trustees. The most common means of perfecting a security interest is by filing a financing statement in the appropriate place, such as the office of the secretary of state. See U.C.C. 9-310 (2001) (requiring that financing statement must be filed to perfect most security interests). Article 9 also provides other methods of perfection, such as having creditors take physical possession of the collateral. See U.C.C. \$ 9313 (2001) (describing circumstances in which security interest can be perfected by taking possession of collateral). If a security interest is perfected, it is senior to most later creditor interests. See U.C.C. \& 9-322 (2001) (describing priority of perfected security interests over later perfected or unperfected security interests).

13. A financing statement is a record containing information, such as the name of the debtor, the name of the secured creditor, and an indication of the collateral. See U.C.C. § 9502(a) (2001) (listing required contents of financing statement). A financing statement serves as a notice that "indicates merely that a person may have a security interest in the collateral indicated. Further inquiry from the parties concerned will be necessary to disclose the complete state of affairs." U.C.C. $\$ 9-502$ cmt. 2 (2001).

14. "Collateral' means the property subject to a security interest or agricultural lien. The term includes: (A) proceeds to which a security interest attaches; (B) accounts, chattel paper, payment intangibles, and promissory notes that have been sold; and (C) goods that are subject of a consignment." U.C.C. $\$ 9-102(12)(2001)$.

15. Perhaps the above scenario is another example of both how the development of cyberspace challenges and tests current legal boundaries and how it will continue to do so. See, e.g., Graeme B. Dinwoodie, (National) Trademark Laws and the (Non-National) Domain Name System, 21 U. PA. J. INT'L ECON. L. 495, 496-97 (2000) (noting that conflict between trademark law and domain name regulatory systems is one of several cyberspace challenges to current legal boundaries).

16. See William F. Alderman \& John Kanberg, Due Diligence in the Securities Litigation Reform Era: Practical Tips from Litigators on the Effective Conduct, Documentation and Defense of Underwriter Investigation, 1176 PLVCORP 177, 208 (2000) (observing that many startup Internet companies lack "significant physical assets such as manufacturing facilities or inventory").

17. See id. at 207-08 (observing that Internet companies "have a large portion of their value tied to intangible assets," particularly "intangible intellectual property"); Marjorie Chertok \& Warren E. Agin, Restartcom: Identifying, Securing and Maximizing the Liquidation Value 
sector has revealed that for most Internet companies filing for bankruptcy, the most valuable remaining assets are intangible assets. ${ }^{18}$ Often, domain names are the only remaining valuable assets, tangible or intangible, as these Internet companies approach insolvency. ${ }^{19}$

As bankruptcy trustees and creditors glimpse the bankruptcy estate, fundamental questions of security interests in domain names and perfection of such interests must be resolved prior to any attempt to determine priority of conflicting interests in the cyber-assets, particularly domain names. Specifically, are domain names personal property that can be used to secure payment and performance of an obligation? If so, what method of perfection should be employed for securitization of domain names? This Article will address these issues and will propose two methods for perfection of security interests in domain names.

Part II will discuss the general perfection schemes under Article 9 of the Uniform Commercial Code (UCC) and the possible federal preemption of state regulations concerning perfection of security interests in certain types of intangible property. ${ }^{20}$ Part III further examines the uneasy existence of both state and federal law on perfection of security interests in intangible corporate assets, such as trademarks, ${ }^{21}$ and suggests that the perfection mechanism for

of Cyber-Assets in Bankruptcy Proceedings, 8 AM. BANKR. INST. L. REV 255, 261-62 (2000) (observing that "[u]nlike typical brick and mortar companies the assets of the typical Internet company are often 'virtual' consisting of intellectual property such as trademarks, trade names, copyrights, and patents, and general intangibles"); Scott J. Driza, Perfecting Security Interests in Intellectual Property, $88 \mathrm{ILL}$. B. J. 162, 162 (2000) (noting that intellectual property is only valuable collateral owned by many upstart companies); E. Lee Reichert, Mergers and Acquisitions in a Dot.com World, 29 CoLo. LAw. 37, 39 (2000) (observing that intellectual property constitutes large portion of value of companies that conduct significant portions of their business activity on Internet); Robert P. Simons, Back to Earth From Cyberspace: Dealing with Business Failure of Internet Companies, NEV. LAw., June 8, 2000, at 12 (noting that "intemet company's assets are intangible in nature and include intellectual property"); Charles Szurgot, Disclosure, Intellectual Capital and Value in the Internet Age, Wallstreetlawyer.com: Security in the Electronic Age, June 1999, available at WL 3 No. 1 GLWSLAW 7 (noting that Internet companies "derive an increasingly large percentage of value from intangible assets and intellectual capital, like brand names, patents and customer loyalty").

18. See Chertok \& Agin, supra note 17, at 296 (describing liquidation of bankrupt Boo. com, whose most marketable assets were technology, intellectual property, and customer lists); A. Mechele Dickerson, From Jeans to Genes: The Evolving Nature of Property of the Estate, 15 BANKR. DEV. J. 285, 298 (1999) (observing difficulty bankruptcy courts will soon face in determining value of cybercompany estates, which consist largely of "intangible cyberassets").

19. See Julie Pitta, The Undertaker, FORBES, Dec. 25, 2000, at 62 (reporting that only remaining assets of bankrupt dot-coms are usually "a domain name and a few chairs").

20. See infra notes 32-58 and accompanying text (discussing UCC's perfection scheme and whether federal law preempts perfection of security interests in intangible assets).

21. See infra notes 60-93 and accompanying text (explaining dual federal and state perfection schemes for intangible corporate property such as trademarks). 
security interests in trademarks may provide some guidance to the formation of a perfection scheme for security interests in domain names. ${ }^{22}$

Unlike the perfection of security interests in trademarks, an attempt to securitize domain names encounters the troublesome issue of proper classification of domain names. Is a domain name a creature of the contract for services between the domain name registrar and the registrant? Is a domain name legal property? Is there a property interest in domain names? Part IV will examine the commercial treatment of domain names in the open market as well as relevant federal statutes and judicial opinions relating to domain names in an attempt to ascertain whether domain names are "personal property" for purposes of secured transactions under Article 9 of the UCC $^{23}$

Part V will propose two methods of perfection of security interests in domain names. The first proposal would involve a state-regulated scheme through which creditors perfect their security interests in domain names by filing a financing statement with the applicable state filing office. ${ }^{24}$ The second proposal would create a scheme, based in federal law, through which creditors perfect their security interests in domain names by electronically filing a financing statement with a domain name registrar who then records the security interest information with the WHOIS database. ${ }^{25}$ The Part concludes by evaluating the strengths and weaknesses of each method. ${ }^{26}$

\section{Perfection and Federal Preemption}

State law historically has governed secured transactions involving personal property. ${ }^{27}$ Prior to the promulgation of Article 9 of the UCC in 1962, creditors relied on security devices such as pledges, "chattel mortgages, conditional sales, trust receipts, factor's liens, and assignments of accounts receiv-

22. See infra notes 94-123 and accompanying text (examining how trademark perfection schemes might provide models for development of domain name perfection schemes).

23. See infra notes 168-249 and accompanying text (considering whether domain names are "personal property" under Article 9 of UCC).

24. See infra note 250-68 and accompanying text (proposing state-regulated perfection scheme for security interests in domain names).

25. See infra notes 269-80 and accompanying text (proposing federal perfection scheme).

26. See infra notes 281-87 and accompanying text (examining relative strengths and weaknesses of federal and state preemption schmes).

27. See Lois R. Lupica, Circumvention of the Bankruptcy Process: The Statutory Institutionalization of Securitization, 33 CONN. L. REV. 199, 202-03 (2000) (discussing common law and state statutes that governed pre-UCC secured transactions); see also Shubha Ghosh, The Morphing of Property Rules and Liability Rules: An Intellectual Property Optimist Examines Article 9 and Banloruptcy, 8 FORDHAM INTELL. PROP. MRDIA \& ENT. L.J. 99, 110 (1997) (noting that Article 9 of UCC is primary source of state law governing secured credit). 
able." ${ }^{128}$ Such security devices were ineffective, confusing, and failed to promote commercial financing. ${ }^{29}$ The original version of Article 9 replaced such pre-UCC devices. ${ }^{30}$ Article 9 went through its first revision in 1972 and was most recently revised in 1999, with the changes becoming effective on July 1 , 2001. ${ }^{31}$

Article 9 governs any "transaction, regardless of form, that creates a security interest in personal property . . . by contract."132 "A security interest is an interest in personal property . . . which secures payment or performance of an obligation." ${ }^{133}$ Such interest, however, does not amount to a transfer of title in the personal property. ${ }^{34}$ Parties generally accomplish perfection of

28. See U.C.C. \$ 9-101 cmt. (1972) (stating that "[t]his Article sets out a comprehensive scheme for the regulation of security interests in personal property and fixtures. It supersedes prior legislation dealing with such security devices as chattel mortgages, conditional sales, trust receipts, factor's liens and assignments of accounts receivable."); Lupica, supra note 27, at 20203 (noting types of devices used pre-UCC); see also In re Cybernetic Servs., Inc., 239 B.R. 917, 920 (B.A.P. 9th Cir. 1999) (noting that "[b]efore the adoption of the UCC, \& variety of personal property security devices were used, including chattel mortgages, that placed title in the mortgagee").

29. See U.C.C. \& 9-101 cmt. (1972) (noting history of Article 9's development). The 1972 version of the Official Comment to \& 9-101 states:

The growing complexity of financing transactions forced legislatures to keep piling new statutory provisions on top of our inadequate and already sufficiently complicated nineteenth-century structure of security law. The results of this continuing development were increasing costs to both parties and increasing uncertainty as to their rights and the rights of third parties dealing with them. The aim of this Article is to provide a simple and unified structure within which the immense variety of present-day secured financing transactions can go forward with less cost and with greater certainty.

Id.; see also Grant Gilmore, The Good Faith Purchase Idea \& the Uniform Commercial Code: Confessions of a Repentant Draftsman, 15 GA. L. REv. 605, 620 (1981) (observing that "[p]reCode personal property security law may be described as closely resembling that obscure wood in which Dante discovered the gates of hell"); Lupica, supra note 27, at 203 (describing preArticle 9 patchwork of laws governing secured transactions and resulting inefficiency and uncertainty).

30. See supra note 28 and accompanying text (describing security devices replaced by Article 9 of UCC).

31. See U.C.C. \$ 9-101 cmt. (2001) (explaining historical background of Article 9); U.C.C. \$ 9-101 cmt. (1972) (same); see also Robert E. Scott, The Politics of Article 9, 80 VA. L. REV. $1783,1785-87$ (1994) (discussing "connections between the institutional frame work of the U.C.C. and the substantive provisions of Article 9" that facilitated development of Article 9).

32. U.C.C. \& 9-109 (2001).

33. U.C.C. \$ 1-201(37) (2001).

34. See U.C.C. \& 9-315(a)(1) (providing that security interest "continues in collateral notwithstanding sale, lease, license, exchange, or other disposition thereof unless the secured party authorized the disposition free of the security interest"); see also In re Cybernetic Servs., Inc., 239 B.R. 917, 920 (B.A.P. 9th Cir. 1999) (noting that "UCC created a single security 
security interests in personal property serving as collateral for commercial transactions by filing a financing statement ${ }^{35}$ describing $^{36}$ or indicating the collateral $^{37}$ with the appropriate state offices. ${ }^{38}$

Article 9 divides collateral into different categories such as goods, quasitangible property, and intangible property. It further subdivides goods into consumer goods, equipment, farm products, and inventory, ${ }^{39}$ quasi-tangible property into instruments, investment property, documents, and chattel paper; and intangible property into accounts, deposit accounts, general intangibles, health-care receivables, and payment intangibles. ${ }^{40}$ The classification of collateral is important because Article 9 requires different technical steps to perfect $^{41}$ security interests for different types of collateral. ${ }^{42}$

The general intangible category is a catch-all category for personal property not belonging to any other category of collateral. ${ }^{43}$ Trademarks, copy-

device, which was not dependent on who had title to the property .... Because transferring title no longer has significance in creating a security interest in personal property, most security interests created after adoption of the UCC do not involve the transfer of title.").

35. See U.C.C. \& 9-310 (2001) (providing general rule that, subject to exceptions, "a financing statement must be filed to perfect all security interests").

36. See U.C.C. \& 9-504 (2001) (stating that "financing statement sufficiently indicates the collateral that it covers if the financing statement provides: (1) a description of the collateral pursuant to Section 9-108(b)"). U.C.C. \& 9-108(b) (2001) states that:

a description of collateral reasonably identifies the collateral if it identifies the collateral by: (1) specific listing; (2) category; (3) ... a type of collateral defined in the Uniform Commercial Code; (4) quantity, (5) computational or allocational formula or procedure; or (6) . . . any other method, if the identity of the collateral is objectively determinable. Id.

37. See U.C.C. $\$ 9-504$ (2001) (stating that "financing statement sufficiently indicates the collateral that it covers if the financing statement provides: (1) a description of the collateral ... or (2) an indication that the financing statement covers all assets or all personal property").

38. See U.C.C. § 9-501 (2001) (listing filing offices for perfection of various types of security interests).

39. See U.C.C. \$ 9-102 cmt. 4a (2001) (listing "the four mutually-exclusive 'types' of collateral that consist of goods: 'consumer goods,' 'equipment,' 'farm products,' and 'inventory'").

40. See U.C.C. \& 9-102 \& cmt. (2001) (providing definitions and classifications of collateral).

41. See supra note 12 (defining perfection).

42. See U.C.C. $\$ 9-309$ (2001) (listing types of security interests that can be perfected by attachment); U.C.C. \& 9-310 (2001) (requiring filing of financing statement as most common method for perfecting security interests in majority of collateral property, but noting exceptions); U.C.C. \& 9-313 (2001) (permitting secured party to perfect certain security interests by taking possession of collateral property); U.C.C. \& 9-314 (2001) (providing perfection of security interest by control of investment property, deposit accounts, letter of credit rights, and electronic chattel paper).

43. See U.C.C. \& 9-102(a)(42) \& cmt. 5d (2001) (defining general intangible personal property). 
rights, and patents do not fall into any category of intangibles and, thus, are in the residual category of general intangibles under Article $9 .{ }^{44}$ Indeed, the Official Comment to UCC $\$ 9-102$ indicates that general intangibles include "various categories of intellectual property" and "rights that arise under a license of intellectual property." ${ }^{\text {"S }}$

Although perfection of security interests in collateral generally is achieved by compliance with state filing requirements, ${ }^{46}$ federal law governs the perfection of security interests in certain types of general intangible collateral, such as registered copyrights. ${ }^{47}$ Section $9-109$ (c) specifically indicates that Article 9 "does not apply to the extent that a statute, regulation, or treaty of the United States preempts this article." 48 However, this preemption exists only to the extent mandated by federal law. ${ }^{49}$

Furthermore, section 9-311(a)(1) provides that the filing of a financing statement is not effective to perfect a security interest in property that is subject to a federal statute "whose requirements for a security interest's obtaining priority over the rights of a lien creditor with respect to the property preempt section 9-310(a)." As the Official Comment to section 9-311 notes, Article

44. See U.C.C. \$ 9-102 cmt. 5d (2001) (defining general intangibles as residual category of personal property).

45. See id. (explaining that general intangibles serve as residual category of personal property). Comment $5(d)$ states that

"[g]eneral intangible" is the residual category of personal property, including things in action, that is not included in the other defined types of collateral. Examples are various categories of intellectual property ... . As used in the definition of "general intangible," "things in action" includes rights that arise under a license of intellectual property, including the right to exploit the intellectual property without liability for infringement. Id.

46. See U.C.C. $\$ 9-310$ (2001) (providing general rule of perfection by filing).

47. The recent trend in case law indicates that courts require a filing with the Copyright Office for perfection of security interests in registered copyrights and a UCC-1 financing statement filed with the appropriate state office for perfection of security interests in unregistered copyrights. See e.g., Acrocon Eng'g, Inc. v. Silicon Valley Bank (In re World Auxiliary Power Co.), 244 B.R. 149, 153 (Bankr. N.D. Cal. 1999) (concluding that "a security interest in an unregistered copyright may be perfected by filing a UCC-1 financing statement with the UCC Office"); Official Unsecured Creditors' Comm. v. Zenith Prods., Ltd. (In re AEG Acquisition Corp.), 127 B.R. 34, 40-41 (Bankr. C.D. Cal. 1991) (finding that Copyright Act preempts UCC for security interests in copyrights and that perfection of registered copyrights requires that security interests must be recorded with United States Copyright Office).

48. U.C.C. $\$ 9-109$ (c) (2001).

49. See Steven O. Weise, The Financing of Intellectual Property Under Revised UCC Article 9, 74 CHI.-KENT L. REV. 1077, 1080 n.7 (1999) (observing that "section 9-109(c)(1) makes clear that Article 9 defers to federal intellectual property law only 'to the extent' that federal law in fact preempts Article 9").

50. U.C.C. \& 9.311(a)(1) (2001). 
9 exempts from the filing provision ${ }^{51}$ "transactions as to which a system of filing . . . has been established under federal law." 52 When "such a system exists, perfection of a relevant security interest can be achieved only through compliance with that system. ${ }^{153}$ The Official Comment mentions civil aircraft as an example of the type of property subject to federal statutes that effectively preempt Article 9 filing provisions. ${ }^{54}$ On the other hand, the Official Comment lists the Assignment of Claims Act of 1940 as an example of a federal statute that "provides for notice to contracting and disbursing officers and to sureties on bonds but does not establish a national filing system and therefore is not within the scope of" section 9-311(a)(1) preemption. ${ }^{55}$

Analyzing both sections 9-109 and 9-311 suggests that federal preemption of state perfection schemes will occur only if the pertinent federal statute requires the preemption and such law provides a national filing system for perfection of the relevant security interests. ${ }^{56}$ How courts analyze the recently revised sections of Article 9 in relation to intangible property governed by federal law such as copyrights, patents, and trademarks remains to be seen. Nevertheless, courts largely already have resolved the question of whether federal trademark law preempts state regulations of security interests in trademarks, ${ }^{57}$ albeit under the former Article $9 .{ }^{58}$

51. See U.C.C. $\$ 9-310$ (2001) (providing general rule and exceptions to perfection by filing).

52. U.C.C. $\$ 9-311 \mathrm{cmt} .2(2001)$.

53. Id.

54. See U.C.C. \$ 9-311 cmt. 2 (2001) (listing civil aircraft as example of type of property preempted by federal statute).

55. Id.

56. See Weise, supra note 49, at 1080 n.7 (stating that Article 9 acknowledges federal preemption only to extent required by federal law). In his treatise, Bankruptcy Judge William L. Norton, Jr., states:

The 1999 revision to UCC Article 9 changes the applicable preemption rules. The revised Article 9's provisions do not apply "to the extent that" a statute, regulation, or treaty of the United States preempts the provision. Federal law thus preempts revised Article 9 only to the extent required by the Federal law, not in its entirety when the subject matter of the security interest is subject to other law.

WIILIAML.NORTON,JR.,NORTONBANKRUPTCY LAW AND PRACTICE 2D $\$ 151: 18$ (2d ed. Supp. 2001).

57. See Am.'s Hobby Ctr. v. Hudson United Bank (In re Am. Hobby Ctr.), 223 B.R. 275, 286 (Bankr. S.D.N.Y. 1998) (noting that "to date there has been little dissent regarding security interests in trademarks; the consensus is that they are controlled by state UCC law" (quoting Alice Haemmerli, Insecurity Interests: Where Intellectual Property and Commercial Law Collide, 96 CoLUM. L. REV. 1645, 1656 (1996))).

58. Former Article 9 provides two relevant provisions pertaining to federal preemption and exception to perfection by filing: Former section 9-104(a) provides that Article 9 is inapplicable to "a security interest subject to any statute of the United States, to the extent that such 


\section{Perfection of Security Interests in Trademarks}

Trademarks are words, phrases, logos, symbols, or devices that are used in association with goods or services to function as source identifiers. ${ }^{59}$ No longer the latest form of corporate assets, ${ }^{60}$ trademarks have become a wellestablished component of corporate value. ${ }^{61}$ Many trademarks are highly valued, ${ }^{62}$ and, not surprisingly, many companies utilize them as collateral in commercial financing. ${ }^{63}$

Under trademark law, the trademark owner does not "own" the words, phrases, logos, symbols, or devices that have been functioning as source

statute governs the rights of parties to and third parties affected by transactions in particular types of property." U.C.C. \& 9-104(a) (2000). Former section 9-302(3) states that UCC filing

is not necessary or effective to perfect a security interest in property subject to ... a statute or treaty of the United States which provides for a national or international registration or a national or international certificate of title or which specifies a place of filing different from that specified in this Article for filing of the security interest.

U.C.C. \& 9-302(3) (2000). Former section 9-302(4) further states that "[c]ompliance with a statute or treaty described in subsection (3) is equivalent to the filing of a financing statement under this Article, and a security interest in property subject to the statute or treaty can be perfected only by compliance therewith." U.C.C. \$9-302(4) (2000).

59. 15 U.S.C. \& 1127 (1994) (defining trademarks).

60. See Lisa M. Vaccaro, Security Interests in Intellectual Property: Towards a Unified System of Perfection, 6 HOFSTRA PROP. L.J. 215, 216 (1993) (noting that beginning in 1960s corporate assets expanded to include intangible intellectual property).

61. See, e.g., JULUUS R. LUNSFORD, JR., GOOD WIILIN TRADE MARKs: COCA-COLA AND COKR, THR COCA-COLA BOTTLER 27 (1955) ("The production plants and inventories of The Coca-Cola Company could go up in flames overnight .... Yet, on the following morning, there is not a bank ... that would not lend this Company the funds necessary for rebuilding, accepting as security only the inherent goodwill in its trademarks 'Coca-Cola' and 'Coke." ).

62. See Discussion, Trademark Vigilance in the Twenty-First Century: A Pragmatic Approach, 9 FORDHAM INTELL. PROP. MEDIA \& ENT. L.J. 823, 827 (1999) (quoting panelist Bret Parker, Colgate-Palmolive Senior Trademark \& Copyright Counsel and noting that Colgate trademark has been appraised at \$4.4 billion); Industry Calls for Stiffer Enforcement of AntiCounterfeiting Laws Abroad, 44 Pat. Trademark \& Copyright J. (BNA), Oct. 1, 1992, at 585, 586 (observing that Coca-Cola trademark is valued at $\$ 24$ billion and Pampers is valued at $\$ 6$ billion); Russell L. Parr, The Value of Trademarks, C913 A.L.I-A.B.A. 229, 235 (1994) (estimating value of Marlboro trademark at $\$ 52$ billion); Allison Sell McDade, Note, Trading in Trademarks - Why the Anti-Assignment in Gross Doctrine Should be Abolished When Trademarks Are Used as Collateral, 77 TEX. L. REV. 465, 465 (1998) (observing that McDonald's trademark was estimated as being worth $\$ 20$ billion and Nike, Kellogg, and AT\&T trademarks are estimated at \$11 billion each).

63. See, e.g., EH Yacht, L.L.C. v. Egg Harbor, L.L.C., 84 F. Supp. 2d 556, 566 (D. N.J. 2000) (noting "the well-established rule that creditors may name trademarks as valuable collateral securing repayment of loans"); Li'l' Red Barn, Inc. v. Red Barn Sys., Inc., 322 F. Supp. 98, 106-07 (N.D. Ind. 1970) (upholding as valid trademark assignment that provided for reassignment of trademark to assignor if assignee defaulted). 
identifiers. ${ }^{64}$ Rather, the trademark owner has the right to enjoin others from using a substantially similar trademark that is likely to cause confusion in the mind of the consumer. ${ }^{65}$ Though trademarks are a form of intellectual property and have become very valuable corporate assets, trademarks cannot be assigned, transferred, or traded without the attached goodwill. ${ }^{66}$ This rule of anti-assignment in gross of a trademark prohibits judgment creditors from levying upon and selling a judgment debtor's trademarks without the associated good will. ${ }^{67}$

Although trademarks and their associated goodwill are used as collateral in secured transactions, perfection of security interests in such intangible property is ambiguous due to the potential conflicts between the Lanham Act, which governs federal trademarks, ${ }^{68}$ and the UCC. ${ }^{69}$ The ambiguity has been

64. Trademark rights are based on use. See United Drug Co. v. Theodore Rectanus Co., 248 U.S. 90, 97 (1918) (concluding that trademark rights arise only from use of trademark in connection with existing business or trade); Buti v. Perosa, S.R.L., 139 F.3d 98, 103 (2d Cir. 1998) (noting that to assert trademark rights, mark must be used in commerce).

65. See, e.g., 15 U.S.C. $\$ 1114(2)$ (1994) (providing that injunctive relief is available to owner of infringed trademark rights); Washington Speakers Bureau; Inc. v. Leading Auths., Inc., 49 F. Supp. 2d 496, 498 (E.D. Va. 1999) (finding that trademark owner had right to enjoin unauthorized use of trademarks as domain names but no ownership rights in such domain names).

66. See Adams Apple Distrib. Co. v. Papeleras Reunidas, S.A., 773 F.2d 925, 931 (7th Cir. 1985) (noting "that a trademark is not a property right in gross which may be sold apart from the business or goodwill with which the trademark has been associated"); Marshak v. Green, 746 F.2d 927, 929 (2d Cir. 1984) (concluding that "sale of a trade name or mark divorced from its goodwill" is invalid "assignment in gross"); J. THOMAs MCCARTHY, 2 MCCARTHY ON TRADEMARKS AND UNFATR COMPETTION \& 18:2 (4th ed. 2001)(discussing rule that "trademark cannot be assigned apart from the good will it symbolizes").

67. See 30 AM. JUR. 2D Executions and Enforcement of Judgments $\S 160$ (1994) (stating that "trademark is not a property right in gross which may be sold apart from the business or good will with which the trademark has been associated. Thus, a judgment creditor may not levy upon and sell a judgment debtor's registered service mark or trademark.").

68. Trademarks are governed by both common law and the Lanham Act. See, e.g., 15 U.S.C. $\S \S 1051-1127$ (1994) (providing federal trademark law); see also Judith L. Church, Intellectual Property Aspects of Corporate Acquisitions, SF14 ALI-ABA 323, 336 (2000) (comparing U.S. trademark law with trademark law of civil law countries); Dan McCuaig, Halve the Baby: An Obvious Solution to the Troubling Use of Trademarks as Metatags, $18 \mathrm{~J}$. MARSHALL J. COMPUTER \& INFO. L. 643, 648-49 (2000) (stating that trademark infringement test is "the same for both common law trademark infringement actions and federal trademark infringement actions under the Lanham Act"); Patricia V. Norton, Note, The Effect of Article 10 bis of the Paris Convention on American Unfair Competition Law, 68 FORDHAML. REV. 225, 227 (1999) (noting that prior to Lanham Act, common law completely provided unfair competition law).

69. See In re Together Dev. Corp., 227 B.R. 439, 442 (Bankr. D. Mass. 1998) (noting that trademark statute is vague; causing understandable confusion as to perfection of security interests in trademarks); see also Thomas L. Bahrick, Security Interests in Intellectual Property, 
a subject of debate during the last fifteen years. ${ }^{70}$ While some commentators believe that perfection of security interests in trademarks is governed by federal statutes, ${ }^{\text {"1 }}$ others assert that the UCC still controls perfection schemes for trademarks. ${ }^{72}$ A few commentators have even advocated dual filings in a state filing office and in the United States Patent and Trademark Office to place third parties on notice of the security interests in trademark collateral. ${ }^{73}$

15 AIPLA Q.J. 30, 37 (1987) (observing confusion as to whether UCC or federal law governs perfection of security interests in intellectual property); Harold R. Weinberg \& William J. Woodward, Jr., Easing Transfer and Security Interest Transactions in Intellectual Property: An Agenda for Reform, 79 KY. L.J. 61,73 (1990-91) (discussing statutory and conceptual "gulf" between state and federal law relating to use of intellectual property as collateral).

70. See Vaccaro, supra note 60, at 234-35 (discussing ABA Task Force on Security Interests in Intellectual Property and its proposals for clarifying laws governing perfection of intellectual property security interests); Weinberg \& Woodward, supra note 69, at $93-94$ (discussing ambiguity, surveying other reform proposals, and offering new proposal). See generally Haemmerli, supra note 57 (reviewing concerns relating to perfection schemes for intellectual property, critiquing proposals advanced by other commentators, and suggesting alternative approaches). Until very recently, the debate involved the former Article 9 and its two relevant provisions pertaining to federal preemption and exceptions to perfection by filing. See supra note 58 for a description of the relevant former provisions, sections 9-104(a) and 9-302. For an argument that dual filings in both the Copyright Office and a state's UCC filing office would perfect security interests in both registered and unregistered copyrights, see generally Jeffrey R. Capwell, Note, Secured Financing in Intellectual Property: Perfection of Security Interests in Copyrights to Computer Programs, 39 SYRACUSE L. REV. 1041 (1988).

71. See Marci Levine Klumb, Note, Perfection of Security Interests in Intellectual Property: Federal Statutes Preempt Article 9, 57 GEO. WASH. L. REV. 135, 138-39 (1988) (contending that Lanham Act, Patent Act, and Copyright Act preempt UCC perfection schemes).

72. See Thomas S. Hemmendinger, Perfecting Security Interests in Intellectual Property, 35 R.I.B.J., Nov. 1986, at 8 (contending that UCC governs perfection of security interests in unregistered trademarks).

73. See Lee G. Meyer et al., Intellectual Property in Today's Financing Market, 19 MAR AM. BANKR. INST. J. 20, 20-21 (Mar. 2000) (stating that to perfect trademark security interests, "assignment[s] should be (1) filed in the PTO reciting the goodwill language described above, (2) filed as a UCC financing statement in the appropriate jurisdiction reciting the elements of the business associated with the trademark, and (3) if they exist filed in compliance with any state trademark requirements"); Raymond T. Nimmer, An Update on Financing with Intellectual Property as Collateral: Part I of II, J. PropRIETARY RTS., Oct. 1997, at 2, 10 (noting that "a dual filing is the safest route for perfecting security interests in trademarks"); see also Roman Cleanser Co. v. Nat'l Acceptance Co. of Am. (In re Roman Cleanser Co.), 43 B.R. 940, 945-46 (Bankr. E.D. Mich. 1984) (noting complicated procedures for perfection of security interests in trademarks proposed by various commentators (citing RUDOLF CALLMAN, UNFAIR COMPETITION, TRADEMARKS AND MONOPOLIES, $\$ 19.62$ (4th ed. 1983); Bahrick, supra note 69, at 45 (recommending that secured party make both federal and state filings); Handler \& Lin, How to Perfect Security Interests in Patents, Trademarks and Copyrights, 11 U.C.C.L.J. 346, $352-53$ (1978))), aff' on other grounds, 802 F.2d 207 (6th Cir. 1986); Vacarro, supra note 60, at 231 (advising lenders "to record their security interests in trademarks under the Lanham Act and under the UCC"). 
Despite such disagreement among commentators, judicial opinions remain relatively uniform in the perfection scheme for security interests in trademarks. ${ }^{74}$ Courts have consistently held that the UCC governs such perfection. ${ }^{75}$ The federal Lanham Act controls only the assignment of trademarks and not security interests in trademarks. ${ }^{76}$ Federal trademark law, in other words, does not preempt state regulations on perfection of security interests in trademarks.

Federal law preempts state law when state law conflicts with federal law, when state law. would frustrate a federal scheme, or when Congress clearly intended to occupy the field. ${ }^{7}$ Congress's failure to define assignment in federal trademark law casts doubt on whether the assignment of a trademark

74. See In re Together Dev. Corp., 227 B.R. at 441 (noting that case law appears to be in uniform agreement as to perfection of security interests in trademarks governed by UCC (citing Joseph v. 1200 Valencia, Inc. (In re 199Z, Inc.), 137 B.R. 778, 782 (Bankr. C.D. Cal. 1992); In re Chattanooga Choo-Choo Co., 98 B.R. 792,796 (Bankr. E.D. Tenn. 1989); In re C.C. \& Co., Inc., 86 B.R. 485, 486-87 (Bankr. E.D. Va. 1988); Roman Cleanser Co. v. Nat'l Acceptance Co. of Am. (In re Roman Cleanser Co.), 43 B.R. 940, 946 \& n.3 (Bankr. E.D. Mich. 1984); Creditor's Comm. of TR-3 Indus., Inc. v. Capital Bank (In re TR-3 Industries, Inc.), 41 B.R. 128, 131 (Bankr. C.D. Cal. 1984))), aff'd sub nom. Trimarchi v. Together Dev. Corp., 255 B.R. 606 (D. Mass. 2000).

75. See Joseph v. 1200 Valencia, Inc. (In re 199Z, Inc.), 137 B.R. 778, 782 (Bankr. C.D. Cal. 1992) (ruling that compliance with Article 9 of UCC, not Lanham Act under preemption theory, perfects security interests in trademarks); Roman Cleanser Co. v. Nat'l Acceptance Co. of Am. (In re Roman Cleanser Co.), 43 B.R. 940, 946 (Bankr. E.D. Mich 1984) (ruling that compliance with Article 9 of UCC perfected security interests in trademark collateral; Creditor's Comm. of TR-3 Indus., Inc. v. Capital Bank (In re TR-3 Indus., Inc.), 41 B.R. 128, 131 (Bankr. C.D. Cal. 1984) (concluding that compliance with Article 9 of UCC perfected security interest in trademark); see also Haemmerli, supra note 57, at 1656 (noting that consensus is that state UCC law governs security interest in trademarks).

76. See Trimarchi v. Together Dev. Corp., 255 B.R. 606, 610-11 (D. Mass. 2000) (concluding that recording of assignments required by Lanham Act does not include security interests). In Official Committee of Unsecured Creditors of America's Hobby Center, Inc. v. Hudson United Bank (In re America's Hobby Center, Inc.), 223 B.R. 275, 286 (Bankr. S.D.N.Y. 1998), the court explained that

[n]one of the Congress, the Supreme Court, the Second Circuit, nor the New York Court of Appeals has spoken definitively on whether a security interest in a trademark is perfected only upon recording it with the trademark office, or whether a filing in accordance with the provisions of the Uniform Commercial Code . . . is adequate. Whereas the weight of such authority is more in line with a determination that the UCC would control, the matter is hardly free from doubt .... However, case law ... clarif[ies] that for federal law to supersede the UCC "the federal statute itself must provide a method for perfecting the security interest."

Id. (citing In re 199Z, Inc., 137 B.R. at 782; In re Roman Cleanser Co., 43 B.R. at 944; In re TR-3 Indus., 41 B.R. at 131).

77. Saridakis v. United Airlines, 166 F.3d 1272, 1276 (9th Cir. 1999); see also Haemmerli, supra note 57, at $1653-55$ (discussing federal preemption problems in commercial law context). 
encompasses a grant of a security interest. ${ }^{78}$ Courts have resolved such doubt by examining the ordinary usage of the term "assignment" at the time of enactment of the federal trademark law. ${ }^{79}$ At the time of enactment, a grant of a "mortgage," rather than an "assignment," was the common way of describing a grant of a security interest. ${ }^{80}$ Further, the Lanham Act refers to the "successor to the business." ${ }^{11}$ This reference suggests that Congress intended an outright assignment of trademarks that are part of a business in the context of the sale of an entire business. ${ }^{82}$ Moreover, Congress had expressed its awareness of the existence of security interests in intellectual property, such as copyrights, by including such liens in the recording requirements for the transfer of copyrights. ${ }^{83}$ Congress opted out of such inclusion when it passed the Lanham Act for trademarks. ${ }^{84}$

Additionally, courts distinguish between security interests and assignments of trademarks. ${ }^{85}$ An assignment of a trademark is an absolute transfer of the entire right to use the mark along with its good will. ${ }^{86}$ The grant of a

78. In re Together Dev. Corp., 227 B.R. 439, 441 (Bankr. D. Mass. 1998).

79. See id. (looking to common usage of "assignment" to determine its meaning within Lanham Act). Congress passed the Lanham Act in 1946, prior to the general adoption of the UCC by the states. Id.

80. Id.

81. See 15 U.S.C. $\$ 1060$ (1999) (stating that no application to register mark under section 1051(b) of this title shall be assignable prior to filing of amendment under section 1051(c) of this title to bring application into conformity with section 1051 (a) of this title or filing of verified statement of use under section 1051 (a) of this title, except for assignment to successor to business of applicant).

82. See In re Together Dev. Corp., 227 B.R. at 441 ("Two other considerations indicate the statute does not apply to security interest filings. First, its reference to the 'successor to the business' suggests Congress had in mind an outright assignment in the context of the sale of an entire business of which the trademark is a part.").

83. See id. ("Congress has expressly included consensual liens in the copyright recording system, thereby demonstrating its awareness of the possibility of such liens and its inclination to make manifest an intention to require their recording ...." ).

84. See id. (concluding that Congress did not provide for recording of security interests in trademarks in Lanham Act).

85. See, e.g., Trimarchi v. Together Dev. Corp., 255 B.R. 606, 610-11 (D. Mass. 2000) (contrasting Lanham Act, which speaks of assignments - not security interests - to Trademarks and Copyright Act, which specifically addresses security interests in copyrights); Joseph v. 1200 Valencia, Inc. (In re 199Z, Inc.), 137 B.R. 778, 782 (Bankr. C.D. Cal 1992) ("'Trademark cases distinguish between security interests and assignments' " (quoting Roman Cleanser Co. v. Nat'1 Acceptance Co. of Am. (In re Roman Cleanser Co.), 43 B.R. 940, 944 (Bankr. E.D. Mich. 1984))); In re C.C. \& Co., Inc., 86 B.R. 485, 486-87 (Bankr. E.D. Va. 1988) (concurring with judgment of other courts that distinguish between assignments and security interests in trademarks under Lanham Act); In re Roman Cleanser Co., 43 B.R. at 944 ("[A] security interest in a trademark is not equivalent to an assignment.").

86. See Acme Valve \& Fittings Co. v. Wayne, 386 F. Supp. 1162, 1165 (S.D. Tex. 1974) ("In order for a transfer of rights in a trademark to constitute a sale or assignment, thereby 
security interest in a trademark is much less than a transfer of entire rights; it is merely an agreement to assign the trademark in the event of default by the debtor. ${ }^{87}$ Further, the Lanham Act does not provide for the filing of notification of security interest in trademarks. ${ }^{88}$ Indeed, the text of section 1060 of the Lanham Act requires the recordation of assignments of trademarks if the assignee does not want the assignment voided without notice as against a subsequent purchaser ${ }^{89}$ Accordingly, the Lanham Act does not provide a perfection scheme for trademarks. ${ }^{90}$

Consequently, Article 9 of the UCC governs the manner of perfecting security interests in trademarks. A financing statement indicating the trademark collateral filed with the applicable state office, often the office of the secretary of state, ${ }^{91}$ is necessary to perfect the security interests in the collateral. ${ }^{92}$ Thus, according to the courts, there is no justification for federal preemption and dual filings in both a state office and the United States Patent and Trademark Office. ${ }^{93}$

vesting title to the trademark in a party, the transfer must be absolute and must relate to the entire rights in the trademark. "); Li'l' Red Barn, Inc. v. Red Barn Sys., Inc., 322 F. Supp. 98, 107 (N.D. Ind. 1970) ("[T] he rule is well established that a mere agreement for the future assignment of a trademark is not an assignment of either the mark itself or the good will attached to it.").

87. See In re Roman Cleanser Co., 43 B.R. at 944 (distinguishing between security interests in trademarks and assignment of trademarks).

88. See Trimarchi, 255 B.R. at 611-12 (noting absence of any federal system for recordation of security interests in trademarks).

89. 15 U.S.C. \& 1060 (1999) provides:

An assignment shall be void as against any subsequent purchaser for a valuable consideration without notice, unless it is recorded in the Patent and Trademark Office within three months after the date thereof or prior to such subsequent purchase. A separate record of assignments submitted for recording hereunder shall be maintained in the Patent and Trademark Office.

Id:; see Trimarchi, 255 B.R. at 610-11 (stating that section 1060 of Lanham Act requires recording trademark assignments if assignee does not want them voided without notice or against subsequent purchaser).

90. See In re Roman Cleanser Co., 43 B.R. at 944 ("Since a security interest in a trademark is not equivalent to an assignment, the filing of a security interest is not covered by the Lanham Act.").

91. See, e.g., In re Together Dev. Corp., 227 B.R. 439, 441 (Bankr. D. Mass. 1998) (noting that Trimarchi failed to make appropriate filing with Secretary of State of Connecticut).

92. See U.C.C. \& 9-310 (2001) (filing provision); U.C.C. \& 9-501 (2001) (filing office provision).

93. See Roman Cleanser Co. v. Nat'l Acceptance Co. of Am. (In re Roman Cleanser Co.), 43 B.R. 940, 945-46 (Bankr. E.D. Mich. 1984) (reviewing commentator's analysis of federal preemption of perfection of security interests in trademarks and concluding that "there is no justification for holding that Code-perfected security interests are not valid"). 
For example, in Trimarchi v. Together Development Corp..${ }^{94}$ the debtor granted a security interest in its trademark to a creditor. ${ }^{95}$ The creditor filed a financing statement with the United States Patent and Trademark Office, not with the Secretary of State for the state of Connecticut, the location of the debtor's principal place of business. ${ }^{96}$ The debtor later filed a voluntary petition for reorganization under Chapter 11 of the United States Bankruptcy Code. ${ }^{97}$ The bankruptcy court ordered the debtor to sell substantially all of its assets, including its trademarks. ${ }^{98}$ The creditor objected to the sale of the trademark, claiming a security interest. ${ }^{99}$ The bankruptcy court ruled that the creditor failed to perfect its security interest in the trademark and, thus, was not entitled to any lien on the proceeds of the sale of the debtor's assets. ${ }^{100}$ The creditor appealed the bankruptcy court's decision to the district court.

The creditor argued that as with copyrights, trademarks are intangible and lack an identifiable situs. ${ }^{101}$ Thus, the efficiency of a single recordation scheme for trademarks compels federal preemption under the Lanham Act. ${ }^{102}$ Consequently, security interests in trademarks occur upon the appropriate filing with the United States Patent and Trademark Office. ${ }^{103}$ The district court rejected this argument upon a careful analysis of Article 9 of the UCC, the Lanham Act, case law, and general policy considerations. ${ }^{104}$

The Trimarchi court observed that federal preemption of the UCC perfection schemes will occur only when relevant federal statutes "specifically and systematically provide for the filing of all security interests in a given form of property."1105 The court noted that "[a] federal intellectual property registration or certificate of title, such as a certificate of federal trademark registration, reveals the name of the registrant and identifies the property but does not provide a list of lienholders. ${ }^{1106}$ Thus, the court explained that:

\footnotetext{
94. 255 B.R. 606 (D. Mass. 2000).

95. Trimarchi v. Together Dev. Corp., 255 B.R. 606, 607 (D. Mass. 2000).

96. Id.

97. Id.

98. Id.

99. Id.

100. Id.

101. See id. at 609 (discussing creditor's argument analogizing intangible nature of copyrights with trademarks in support of preemption theory).

102. See id. (discussing creditor's argument that as with copyrights, intangible nature of trademarks and efficiency of single recordation system compels preemption treatment for trademarks in manner similar to copyrights).

103. See id. (noting creditor's contention that as with copyrights, federal trademark assignment registration preempts any state requirements).

104. See id. at 610-12 (analyzing whether Lanham Act preempts UCC's filing requirements).

105. Id. at 612 (internal quotations omitted).

106. Id.
} 
national registration alone, without any federal system for the recordation of security interests, . . . would leave the holder of a security interest with no means of recording or perfecting that interest. Absent a reliable means of verifying the status of their collateral, secured lenders would be more reluctant to extend credit. Such a result would be inconsistent with the stated purpose of Article 9 of providing a "simple and unified structure" for secured transactions. ${ }^{107}$

The court ruled that the Lanham Act does not preempt the UCC's filing requirements and that the perfection of a security interest in a trademark is governed by Article 9 of the UCC. ${ }^{108}$ Moreover, the court also noted that "in 1988 the Senate passed a bill that, among other things, would have created a federal filing of security interests in trademarks and brought both the recordation of and the priority of security interests in trademarks into conformity with the counterpart copyright provisions." 109 However, the portion of the bill related to security interests did not pass the House, thereby leaving the UCC to govem security interests in trademarks. ${ }^{110}$

The Trimarchi decision is consistent with precedents in this area. ${ }^{111}$ In Official Committee of Unsecured Creditors of America's Hobby Center $v$. Hudson United Bank (In re America's Hobby Center), ${ }^{112}$ the plaintiff sought a declaratory judgment that the defendant bank did not have a perfected security interest in the debtor's "Megatech" trademark. ${ }^{113}$ Before the suit, the defendant bank's had security interests in all of the debtor's present and future trademarks. ${ }^{114}$ At the beginning of its analysis, the court noted that Congress, the Supreme Court, the Second Circuit, and the New York Court of Appeals have not addressed definitively how a security interest in a trademark is

107. Id.

108. Id. at 611-12.

109. Id. at 611 .

110. Id.; see Stuart M. Rilback, Intellectual Property Licenses, The Impact of Bankruptcy, in UNDERST ANDNG THR INTELLECTUAL PROPERTY LICENSE 185, 211 n.97 (PLI Intellectual Property Course Handbook Series No. G-620, 2000) (discussing history of bill and effect of House's failure to pass it).

111. See, e.g., Roman Cleanser Co. v. Nat'l Acceptance Co. of Am. (In re Roman Cleanser Co.), 43 B.R. 940, 945-46 (Bankr. E.D. Mich. 1984) (refusing to use Lanham Act to preempt state UCC law with respect to security interests in trademarks); Creditor's Comm. of TR-3 Indus., Inc. v. Capital Bank (In re TR-3 Indus., Inc.), 41 B.R. 128, 131 (Bankr. C.D. Cal. 1984) (finding that "[i]t was not the purpose or intent of Congress in enacting the Lanham Act to provide a method for the perfection of security interests in trademarks, tradenames or applications for the registration of the same").

112. 223 B.R. 275 (Bankr. S.D.N.Y. 1998).

113. Official Comm. of Unsecured Creditors of Am.'s Hobby. Ctr. v. Hudson United Bank (In re Am.'s Hobby Ctr.), 223 B.R. 275, 286 (Bankr. S.D.N.Y. 1998).

114. Id. 
perfected. ${ }^{115}$ Nevertheless, the court concluded that case law and the then proposed UCC revision clarified that "for federal law to supersede the UCC the federal statute itself must provide a method for perfecting the security interest."116 Based on this conclusion, the court found enough disagreement in the law to warrant further litigation, denying defendant bank's motion to dismiss. ${ }^{117}$

Similarly, in Roman Cleanser Co. v. National Acceptance Co. of America (In re Roman Cleanser Co.) ${ }^{118}$ the court compared the filing provisions under the Copyright Act and the Lanham Act and concluded that unlike the Copyright Act, the Lanham Act does not cover security interests in trademarks. ${ }^{19}$ The court reasoned that if Congress intended that security interests in trademarks be perfected by filing with the United States Trademark Office, it could have expressly provided for such a filing, as it did in the Copyright Act. ${ }^{120}$ The court ruled that the Lanham Act only covered assignments of trademarks and not security interests. ${ }^{121}$ Accordingly, a security interest in a trademark is governed by Article 9 of the UCC. ${ }^{122}$

In summary, although the Lanham Act governs federal trademarks, there is no federal preemption of the perfection of security interests in trademarks. State regulations, through the adoption of Article 9 of the UCC, control the perfection of security interests in trademarks. In recent years, the growth of e-commerce has given rise to explosive growth of domain names. Domain names have been compared to trademarks because domain names are comprised of words and attain value dependent on their attending use. ${ }^{123}$ The next part of this Article examines whether such a comparison is correct and

115. Id.

116. Id. (internal quotations omitted).

117. Id. at 287.

118. 93 B.R. 940 (Bankr. E.D. Mich. 1984).

119. See Roman Cleanser Co. v. Nat'l Acceptance Co. of Am. (In re Roman Cleanser Co.) 43 B.R. 940, 946 (Bankr. E.D. Mich. 1984) (noting that UCC commentary did not recognize Lanham Act filing provisions as equivalent to filing provisions of Article 9 of UCC).

120. See id. at 946 ("If Congress intended to provide a means for recording security interests in trademarks ... it would have been simple so to state.").

121. Id. at 944.

122. Id.

123. Dorer v. Arel, 60 F. Supp. 2d 558, 560 n.9 (E.D. Va. 1999) (observing that domain names are addresses and derive their value primarily from their use). The more that Internet users visit a web site by using its domain name, the higher the value of the domain name. See id. at 561 (arguing that domain name registration entails only contract rights and that its value derives solely from how registrant exploits it). In this context, a domain name is more analogous to a trademark and its attached goodwill than a patent whose value is independent from its content or the owner's goodwill. See id. at $560 \mathrm{n} .9$ (discussing how domain names are more similar to trademarks than patents). 
whether the existing perfection scheme of security interests in trademarks should be the same for domain names.

\section{Domain Names as General Intangibles}

\section{A. Domain Names as the New Valuable Corporate Assets}

In recent years companies rushed to the Internet to establish their presence, ${ }^{124}$ utilizing the worldwide network of computers to sell products and services through various business models, ranging from customer to customer (C2C), business to customer (B2C), and business to business (B2B) models. ${ }^{125}$ To stand out from the crowded dot-com world, e-companies attempt to quickly brand themselves on the Internet. ${ }^{126}$ Through branding, e-companies seek to get Internet users - their potential customers - to visit and revisit their sites. ${ }^{127}$

124. See Robert H. Zakon, Hobbes' Internet Timeline v5.4, at http://www.zakon.org/robert/ internet/timeline (last modified Aug. 23, 2001) (tracing development of Internet from 1950s through present). In January 1996, there were only 100,000 web sites on the World Wide Web. Less than five years later, as of September 2000, there are 21,166,912 web sites on the World Wide Web. Id.

125. See ECON.\& STATISTICS ADMIN.,U.S. DEP'T OF COMMRERCE, DigrTALECONOMY 2000 (2000), at http://www.esa.gov/de2000.pdf (last visited Oct. 24, 2001) (providing comprehensive analysis of various C2C, B2C, and B2B business models); GoLDMAN SACHS, B2B: 2B OR Nor 2B? (Nov. 12, 1999), available at http:/www.gs.com/hightech/research/b2b (last visited Oct. 24,2001 ) (providing comprehensive analysis of business to business e-commerce); see also Suein Hwang \& Mylene Mangalindan, Yahoo's Grand Vision for Web Advertising Takes Some Hard Hits, WALL ST. J., Sept. 1, 2000, at Al (facing concern about failed promise of Web-based advertising Yahoo's new Corporate Yahoo platform aims at moving Yahoo into business-tobusiness market by integrating Yahoo's portal into companies' internal Web networks); Don Tapscot, Virtual Webs Will Revolutionize Business, WALL ST. J., Apr. 24, 2000, at A38 ("B2B exchanges pave the way for the new model ... company in the digital economy ... vertically integrated ... corporation[s are] giving way to a form of wealth creation called the business web. [It] is a distinct system of suppliers, distributors, commerce services providers, infrastructure providers and customers that use the Internet.").

126. See Nguyen, supra note 6, at 952-58 (discussing "branding" in e-commerce).

127. See Andrew J. Frackman \& Robert M. Stern, Federal Circuit Ruling, Largely Ignored. Impacts Patent Infringement Equation: Effect Predicted Particular for Business Method Litigation, N.Y.L.J., Apr. 17, 2000, at S7 (noting that "the key to success on the Internet turns on branding and the first-mover advantage"); James F. Haggerty, Marketing Your Firm: Toward Common Sense Branding Strategies, N.Y.L.J., Mar. 14, 2000, at 5 (observing that "[t]he rise of the Internet and other technologies, in fact, is where this focus on 'branding' all began"); Rachel King, What's Wireless.com Worth? Maybe \$15M, 2000 WL 4064606, 1/31/00 Interactive Wk. From ZDWire (reporting that many dot.com companies spend $\$ 100$ million in brand campaigns); Che Odom, Miam DaIIY BUS. REV., June 27, 2000, at Al, LEXIS American Lawyer Media File (reporting that use of such names as Compaqvirtualbank.com, EMCvirtualbank.com, and Textronvirtualbank.com will enable VirtualBank and its business partners Compaq, EMC Corp., and Textron Financial Corp. to appeal to worker loyalty, allowing this now banking arrangement to serve as "a useful inducement to attract and retain talent" at those participating companies); Joe Starkey (N.Y. Times), Brand-Building More Important to Web 
Their business model was to grow quickly at first and to earn profits later. ${ }^{128}$ A way to achieve such dreams overnight is to own a generic domain name that is memorable and accessible by everyone. ${ }^{129}$ The "right" domain name for Internet branding purposes is a single word with very few characters that describes the products or services offered at the web site. ${ }^{130}$ Internet consumers who want a particular product, but who do not know which websites they should visit, will most likely search for the appropriate website by keying the common name of the product (such as wine or computers). ${ }^{131}$

Sites Online Companies Scramble to Stand Out From Crowd, reprinted in MINNEAPOLIS-ST. PAUL STAR TRIB., Jan. 24, 2000, at 5D ("In the famous cocktail-party scene in 1967's landmark film 'The Graduate,' a helpful older man whispers a single word of business advice to callow, befuddled young Benjamin, played by Dustin Hoffman: 'Plastics.' Remake the movie today and you'd have to change the line to 'Branding.'").

128. See Dickerson, supra note 18, at 299 (observing that "cybercompanies seem to be highly valued because of investor's view of their projected growth, not because of current profits"); Jim Kerstetter, Finding the Right Formula: Making Money on the Net ls Trickier Than Anyone Suspected, BUs. WK., Oct. 23, 2000, at 44 (reporting that difficulties of dot-com companies have lead to questions about viability of their business models); Scott McNealy, It's Like . . Businesses Built on Metaphors Still Need Value, ForBes ASAP, Oct. 2, 2000, at 47 ("Startups may put rapid growth ahead of profits for a time, but eventually they will have to return to the true nature of business. They will have to charge more than the cost of the goods and services they deliver, and make a profit."); see also Madlyn Gleich Primoff \& Erica G. Weinberger, E-Commerce and Dot-Com Bankruptcies: Assumption, Assignment and Rejection of Executory Contracts, Including Intellectual Property Agreements, and Related Issues Under Sections 365(c), 365(e), and 365(n) of the Bankruptcy Code, 8 AM. BANKR. INST. L. REV. 307, 307 (2000) (reporting that during 2000 "scores of dot-com companies have been sold . .., shut down or have filed for protection under title 11").

129. See Lee. J. Plave, ACPA Gives Franchisors New Weapón in War Against Cybersquatting, FRANCHISING BUS. \& L. ALRRT, Jan. 2000, at 1 (recognizing domain names have become important part of branding and commercial identification); Nick Wingfield, The Game of the Name: Thinking Up the Perfect Address Crucial; Just Hope Nobody Else Owns It, WALL ST. J., Nov. 22, 1999, at R14 (reporting that budding Internet entrepreneurs who search for right name for their new companies encounter "nightmare" process because most memorable dot-com addresses are no longer available and selecting difficult to remember company name presents problem of users forgetting name).

130. See Jonathan Lambeth, the telegraph.com: Domainia as net names go for millions, DAII Y TELEGRAPH, June 8, 2001, available at 2000 WL 21888662 (reporting that offer of 4.4 million pounds for inactive web site e-buy.com for "an international department store," has been turned down by its owner and that BrainwareMedia paid \$8 million for mp3audiobooks.com to Boston resident); Thomas E. Weber, Register.Com Aims to Market Internet Addresses to Everyone, WALL ST. J., Apr. 1, 1999, at B7 ("Domain names have evolved into one of the Internet's most important commodities - and an increasingly scarce resource. Though the universe of online addresses is theoretically unlimited, the best addresses get snapped up quickly. A latecomer might find himself stuck with an unwieldy address like 'joespizzaofbrooklyn. com' instead of the easier to type, and remember, 'joes.com.'").

131. See Dorer v. Arel, 60 F. Supp. 2d 558, 561 (E.D. Va. 1999) ("[T]here is a lucrative market for certain generic or clever domain names ... [that are] extremely valuable to Internet entrepreneurs.... A domain name with significant value on the open market certainly would 
To reach these consumers, Internet companies purchase generic domain names, such as wine.com or computers.com, at high prices. ${ }^{132}$

The overnight branding dream has created a secondary market for domain names. ${ }^{133}$ Because most, if not all, generic and memorable domain names are no longer available through accredited registrars such as Network Solutions, Inc. (NSI), Internet companies can obtain these desired corporate assets through the secondary market at high prices. ${ }^{134}$ In the secondary market, domain names are speculative commodities. ${ }^{135}$

\section{B. Domain Names Valuation}

The secondary market for domain names is a flourishing industry that has enticed established e-companies such as $\mathrm{NSI}^{136}$ and Register.com ${ }^{137}$ to enter

be an attractive . . . target for a judgment creditor . ..."). The Dorer court also noted that the plaintiffs do not claim that their domain has any open market value as would the domain name "computers.com." Id. at $561 \mathrm{n} .14$; see Johnson, supra note 1 (reporting that new owner of business.com paid $\$ 7.5$ million for domain name because he believes that "[w]ith business.com, $85 \%$ of the brand-building is already done"); see also Brookfield Communications, Inc. v. W. Court Entm't Corp., 174 F.3d 1036, 1044-45 (9th Cir. 1999) (noting that Internet users who do not know domain name of site for which they are looking have two options: trying to guess proper domain name or seeking assistance of Internet search engine); Playboy Enters., Inc. v. Netscape Communications Corp., 55 F. Supp.2d 1070, $1074-76$ (C.D. Cal. 1999) (denying plaintiff's motion for preliminary injunction upon finding that use of generic terms "playboy" and "playmate" as key words or search terms does not amount to trademark infringement or dilution), aff'd, 202 F.3d 278 (9th Cir. 1999).

132. See Dorer, 60 F. Supp. 2d at 561 (noting that certain domain names may be "extremely valuable to Internet entrepreneurs"); see also SUBMERGEDideas.com, Top Domain Sellers, at http:/www.submerged-ideas.com/valuation/topdomainsales.htm (current as of June 30,2001 ) (reporting that wine.com sold at between $\$ 3.3$ and $\$ 3.9$ million).

133. See Wendy R. Leibowitz, Going Once, Going Twice-Soldl Domain Name Market Heats $U_{p}$, NAT'L L.J., Mar. 28, 1998, at B6 (reporting on domain name sales in secondary market); BofA Was Winning Bidder of Loans.com Web Domain, WALL ST. J., Feb. 8, 2000, at B15 (reporting that Bank of America Corp. bought Loan.com for \$3 million at auction sale held by GreatDomains.com).

134. See Leibowitz, supra note 133, at B6 (reporting on domain name brokerage business on Internet); Wingfield, supra note 5 (reporting on demand for and scarcity of memorable domain names, and on domain name speculators who register domain names hoping to sell them at substantial markups).

135. See Karen Kaplan, Domain Name Trade Gives Rise to Whole New Breed of Brokers Internet: They're Betting That the Buying and Selling of Web Addresses Will Be Big Business for a Long Time to Come, L.A. TMMES, Dec. 13, 1999, at Cl (reporting on secondary market for domain names); see also David Adlerstein, Name of the Game, S. FLA. Bus. J., Mar. 24, 2000, at $49 \mathrm{~A}$ (reporting start-up companies are cashing in on domain name aftermarket).

136. See Leslie Walker, The Name of the Game Is Names, WasH. Post, June 22, 2000, at E1 (reporting that Network Solutions plans to enter "online market where people will be able to buy, sell and appraise previously owned domain names").

137. See Clint Boulton, Register.com Dips into Domain Reselling Well, internetnews.com, Sept. 15, 2000, at http://www.intemetnews.com/bus-news/article/0,33461201,00.html (report- 
the market. ${ }^{138}$ Even well-established brick and mortar companies such as Proctor and Gamble are in the speculation market for domain names. ${ }^{139}$ The secondary market for domain names often has been compared to real estate speculation. ${ }^{140}$ Many web sites in this industry offer a broad range of services, including sales, purchase, and valuation of domain names. ${ }^{141}$ Auctioning is the common sale method employed by these web sites. ${ }^{142}$

Many domain name brokerage web sites offer various valuation models to estimate the value of domain names. ${ }^{143}$ Most of these web sites provide crude and simple valuation models for potential domain name buyers and sellers to employ. ${ }^{144}$ For example, GreatDomains, one of the two pioneer companies in this industry, employs a valuation model called the "four C's."145 These four C's are Characters, Commerce, .Com, and Comparables. ${ }^{146}$ Each

ing that Register.com bought Afternic.com, pioneer in domain resales, for $\$ 49.4$ million in stock and cash).

138. Besides Network Solutions Inc. and Register.com, there are a number of companies operating in the domain name resale business. These Internet companies include http://www. greatdomains.com, http://www.domainiq.com, and http://www.domainart.com (last visited Oct. $24,2001)$.

139. See Cynthia Flash, Are They Cybersquatters or Cyberentrepreneurs?, CMP TECHWEB NEWs, July 20, 2000, available at http://content.techweb.com/wire/story/TWB20000720\$0006 (reporting that Proctor and Gamble is among large corporations selling at high prices generic domain names that they had registered); Patrick Larkin, Profit.com: $P \& G$ Sells 'Net names, CIN. Post, Aug.30, 2000, at 6B (reporting that Procter and Gamble is selling almost 100 generic domain names, registered in 1995, through auction website GreatDomains.com).

140. See Wingfield, supra note 5 (reporting that according to GreatDomains.com, online domain brokerage has more promise than traditional real estate brokerage); see also Press Release, BuyDomains.com, Are All the Great Domain Names Taken? The Rise of the Secondary Market (Mar. 6, 2000), available at http://www.buydomains.com/pr0306.html ("Intemet domain names are the real estate equivalent to location, and with millions of high visibility names taken, the secondary market, where resellers reign, is where the action is." (quoting Mike Mann, CEO of BuyDomains.com)).

141. See, e.g., http://www.greatdomains.com (last visited Oct. 24, 2001) (listing services offered); http://www.buydomains.com (last visited Oct. 24, 2001) (same); http://www.domains. com (last visited Oct. 24, 2001) (same); http:/www.domainsauction.com (last visited Oct. 24, 2001) (same).

142. See, e.g., http://www.greatdomains.com (last visited Oct. 24, 2001) (noting use of auctions); http://www.domainsacutions.com (last visited Oct. 24, 2001) (same).

143. See, e.g., http://www.greatdomains.com (last visited Oct. 24, 2001) (showing models to estimate value of domain names); http:/www.domainiq.com (last visited Oct. 24, 2001) (same); http://www.domainmart.com (last visited Oct. 24, 2001) (same).

144. See, e.g., http://www.greatdomains.com (last visited Oct. 24, 2001) (noting valuation models available); http://www.domainiq.com (last visited Oct. 24, 2001) (same); http://www. domainmart.com (last visited Oct. 24, 2001) (same).

145. See http://www.greatdomains.com/support/AppraisalAbout.htm (last visited Oct. 24, 2001) (describing "4C valuation model").

146. Id. 
domain name is rated on the first three criteria from a scale of zero to four stars. ${ }^{147}$ Higher star ratings indicate more valuable domain names. ${ }^{148}$ Great Domains.com then compares this preliminary rating to those of previously purchased domain names to determine the final value. ${ }^{149}$ This last step represents the fourth criteria of the valuation model. ${ }^{150}$

Regarding the Characters criteria, short domain names generate higher ratings than long domain names because the former are generally easier to remember and to spell and have more impact. ${ }^{151}$. A domain name with fewer than five characters receives four stars, while one over twenty characters long is substantially less valuable. ${ }^{152}$ The sliding scale of the rating system gives a domain name with six to ten characters three stars, one with eleven to fifteen characters two stars, one with sixteen to twenty characters one star, and one beyond twenty characters no stars. ${ }^{153}$

Domain names having the potential to attract traffic to websites and thereby generate revenue are highly valued under the Commerce criteria. ${ }^{154}$ In other words, these domain names are highly marketable. ${ }^{15 s}$ Like most brand names, domain names that are "based on well-known phrases, or are closely associated with a business opportunity with a sizable market share, enjoy a favorable position."156

Domain names registered in the .Com top-level domain earn a four-star rating. ${ }^{157}$ GreatDomains.com bases this criteria on the belief that .Com conveys a sense of exclusivity equivalent to residing in New York, Paris, or Singapore. ${ }^{158}$ Thus, owning a domain name in the top-level domain .Com is an instant branding that generates premium ratings. ${ }^{159}$

Finally, the Comparables criteria involves a comparison of the domain name at issue to previously purchased names. ${ }^{160}$ This comparison ensures an appraisal price that reflects current fair market value. ${ }^{161}$ GreatDomains.com

$\begin{array}{ll}\text { 147. } & I d . \\ 148 . & I d . \\ 149 . & I d . \\ 150 . & I d . \\ 151 . & I d . \\ 152 . & I d . \\ 153 . & I d . \\ 154 . & I d \\ 155 . & I d \\ 156 . & I d . \\ 157 . & I d . \\ 158 . & I d . \\ 159 . & I d . \\ 160 . & I d . \\ 161 . & I d .\end{array}$ 
claims to have one of the largest databases of sales and appraisal data as a result of using this method. ${ }^{162}$

Recently, GreatDomains.com sold Loans.com to Bank of America for \$3 million ${ }^{163}$ That sale is among the highest prices ever paid for a domain name. ${ }^{164}$ Other high profile domain name acquisitions include Business.com for $\$ 7.5$ million and Wine.com for $\$ 3.5$ million. ${ }^{165}$ At least one expert in the domain name resale industry believes that "it's a sign the domain business is maturing that its assets - the names - are being resold to those who have the highest-value use for them. ${ }^{1166}$ Furthermore, that same expert does not expect the million-dollar name sales to vanish after the dot-com fever has subsided because domain names identify companies on the Internet, and valuable domain names may significantly reduce advertising costs. ${ }^{167}$

The commercialization of domain names in the open market is a current phenomenon, unexpected before the arrival of e-commerce on the World Wide Web. The fact that individuals are treating domain names as commodities begs the question of whether domain names are or should be property in the eyes of the law.

\section{Domain Names and Property Interests}

\section{Domain Name Formation}

Deciding whether domain names are a form of intangible property for purposes of secured transactions requires an examination of domain name formation. A domain name registration is a creature of a service contract between a domain name registrar (such as NSI) and a domain name registrant. ${ }^{168}$ Until recently, NSI held the exclusive right to assign domain names

162. Id.

163. See BofA Was Winning Bidder of Loans.com Web Domain, WaLL ST. J., Feb. 8, 2000, at B15 (reporting that Bank of America Corp. bought Loans.com for $\$ 3$ million at auction sale held by GreatDomains.com).

164. See Bank of America Buys Loans.com for \$3 Million at GreatDomains. com in the Highest Price Ever Paid for a Domain Name at Auction, BUs. WIRE, Feb. 8, 2000, Westnews, BWIREPLUS (noting that Loans.com sale was highest ever at auction as of Jan.28, 2000); TOP Domain Sales, at http://www.submerged-ideas.com/valuation/topsales.htm (current as of June 30,2001 ) (listing high profile domain name sales).

165. See Johnson, supra note 1 , at A1 (reporting that eCompanies paid $\$ 7.5$ million in stock and cash to Texas entrepreneur for Business.com domain name); Janis Mara \& Erick Gruenwedel, Name that Domain, MEDIAWEEK, Mar. 27, 2000, at IQ10, available at 2000 WL 14721382 (reporting that VirtualVineyard.com bought Wine.com for $\$ 3.3$ million).

166. See Walker, supra note 136, at E1 (interviewing Jim Rutt, chief executive officer of Network Solutions).

167. Id.

168. Network Solutions, Inc. v. Umbro Int'l, Inc., 529 S.E.2d 80, 86 (Va. 2000) (quoting 
in the top-level domains such as .com, gov; .org, .net, and .edu. ${ }^{169}$ Currently, an initial two-year domain name registration with NSI costs $\$ 35$ per year and is renewable in perpetuity thereafter for successive one-year terms. ${ }^{170}$

NSI assigns domain names on a first-come, first-serve basis by comparing new applications with a database of existing domain names to prevent duplication of previously registered names. ${ }^{171}$ NSI then matches each domain name

Dorer v. Arel, 60 F. Supp. 2d 558, 561 (E.D. Va. 1999)); see VeriSign Service Agreement, at $\mathrm{http} / / \mathrm{www}$. netsol.com/en_US/legal/service-agreement.jhtml (last visited Oct. 18, 2001) (giving service contract for NSI customers); see also Brookfield Communications, Inc. v. W. Coast Entm't Corp., 174 F.3d 1036, 1044 (9th Cir. 1999) (explaining NSI's role in domain name system); Lockheed Martin Corp. v. Network Solutions, Inc., 985 F. Supp. 949, 953 (C.D. Cal. 1997) (same).

169. See Lockheed Martin Corp., 985 F. Supp. at 953 ("Under a contract with the National Science Foundation, NSI manages domain name registrations for the '.com,' '.net,' '.org,' '.edu,' and '.gov' top-level domains."); A. Michael Froomkin, Wrong Turn in Cyberspace: Using ICANN to Route Around the APA and the Constitution, 50 DUKE L.J. 17, 57 (2000)("The NSF-NSI [National Science Foundation-Network Solutions, Inc.] 'Cooperative Agreement' gave NSI a monopoly over .com registrations that it would ultimately build into a multi-billion dollar business; the monopoly originally was scheduled to expire in September 1998."). NSI is no longer the exclusive registrar. More than fifty domain name registrars exist for the .com, .net, and .org top-level domains. See Register.com, Inc. v. Verio, Inc., 126 F. Supp. 2d 238, 238, 242 n.1 (S.D.N.Y. 2000) (noting that "Network Solutions, Inc. ("NSI") formerly enjoyed a monopoly as the only domain name registrar"). "NSI still operates and maintains the top-level domain name servers and zone files which enable the other registrars to access the DNS [Internal Domain Name System] and to transmit domain name registration information for the .com, net, and .org top level domain names to the [Internet Domain Name] System." Id.

170. See VeriSign Service Agreement, ๆ 4, at http://www.netsol.com/en_US/legal/serviceagreement.jhtml (last visited Oct. 18, 2001) (listing contract provisions of service agreement). The agreement states:

As consideration for the services you have selected, you agree to pay Network Solutions the applicable service(s) fees set forth on our Web site at the time of your selection [currently \$35 dollars per year]. All fees are due immediately and are nonrefundable .... Unless otherwise specified, each Network Solutions' service is for a two-year initial term and renewable in perpetuity thereafter for successive one-year terms. Any renewal of your services with us is subject to our then current terms and conditions and payment of all applicable service fees at the time of renewal.

Id.

171. See Brookfield Communications, Inc., 174 F.3d at 1044 (describing role of NSI in domain name registration process). The court noted:

To obtain a domain name, an individual or entity files an application with Network Solutions listing the domain name the applicant wants. Because each web page must have an ... unique domain name, Network Solutions checks to see whether the requested domain name has already been assigned to someone else. If so, the applicant must choose a different domain name. Other than requiring an applicant to make certain representations, Network Solutions does not make an independent determination about a registrant's right to use a particular domain name. 
to the corresponding Internet Protocol (IP) number for the desired Internet site. ${ }^{172}$. The company performs such services pursuant to a domain name service agreement whereby registrants must make certain representations about their rights to use their domain names and the fact that this use does not interfere with the rights of another party. ${ }^{173}$ Furthermore, registrants must agree to be bound by NSI's "Uniform Domain Name Dispute Resolution Policy" as approved by the Internet Corporation for Assigned Names and Numbers (ICANN) on October 24, 1999. ${ }^{174}$

\section{Domain Names: Contractual Rights or Intangible Property?}

Domain names arguably entail contractual rather than property rights because they are the product of service agreements between domain name registrars and registrants. ${ }^{175}$ This contracted-for service is similar to "owning" telephone numbers. ${ }^{176}$ It has the potential for commercial exploits that may

Id.; see Lockheed Martin Corp., 985 F. Supp. at 953 (noting that users may choose any available second-level domain name).

172. See Lockheed Martin Corp., 985 F. Supp. at 953 (listing functions of NSI). The court stated:

NSI performs two function in the domain name system. First, it screens domain name applications against its registry to prevent repeated registrations of the same name. Second, it maintains a directory linking domain names with the IP numbers of domain name servers. The domain name servers, which are outside of NSI's control, connect domain names with Internet resources such as Web sites and email systems.

Id.

173. VeriSign Service Agreement, I 17, at http:/www.netsol.com/en_US/legal/serviceagreement.jhtml (last visited Oct. 18, 2001).

174. Id. at ๆ 8; seeVeriSign Dispute Policy, at http://www.netsol.com/en_US/legal/disputepolicy.jhtml (last visited Oct. 18, 2001) (detailing dispute agreement and ICANN approval).

175. Dorer v. Arel, 60 F. Supp. 2d 558, 561 (E.D. Va. 1999).

176. Id.; see Panavision Int'l v. Toeppen, 141 F.3d 1316, 1325 (9th Cir. 1998) (comparing domain names to vanity telephone numbers based on trademarks, such as 1-800-HOLIDAY for Holiday Inns); Lockheed Martin Corp. v. Network Solutions, Inc., 985 F. Supp. 949, 957-58 (C.D. Cal. 1997) (analogizing function of domain names and telephone numbers). But see Name.Space, Inc. v. Network Solutions, Inc., 202 F.3d 573, 584-85 (2d Cir. 2000) (warning against adopting analogy between domain names and telephone number mnemonics because "the nature of domain names is not susceptible to such a uniform, monolithic characterization"). The court continued:

As the Supreme Court has stated in an analogous and related context, "aware as we are of the changes taking place in the law, the technology, and the industrial structure related to telecommunications, ... we believe it is unwise and unnecessary definitively to pick one analogy or one specific set of words now."

Id. (quoting Denver Area Educ. Telecomms. Consortium, Inc. v. FCC, 518 U.S. 727, 742 (1996) (Breyer, J., plurality opinion)). 
generate significant return for the registrant. ${ }^{177}$. However, the value of the domain name often depends on how the registrant uses it. ${ }^{178}$ Consequently, a domain name without value or goodwill added by the user is usually not valuable. ${ }^{179}$

The electronic medium of the Internet and the recent growth of e-commerce, however, have challenged the notion that domain name value is dependent on use. Many people now consider domain names to be valuable assets irrespective of any goodwill attached to them. ${ }^{180}$ Parties are trading these names in the open market at high prices unrelated to their content or goodwill. ${ }^{181}$ These domain names are often generic words because the market rewards genericness with higher prices. ${ }^{182}$

The classification of domain names as either property or contracts is an issue of first impression with which courts have struggled. ${ }^{183}$ However, the few courts that have faced the issue did not focus on classification but rather on how registrants form and use domain names. ${ }^{184}$ For example, in Umbro

177. See Dorer, 60 F. Supp. 2d at 561 (recognizing "1-800-COLLECT" and "1-800FLOWERS" as two extremely valuable commercial tools); Lockheed Martin Corp., 985 F. Supp. at 958 ("Domain names, like telephone numbers, are also valuable to trademark holders when they make it easier for customers to find the trademark holder.").

178. See Dorer, 60 F. Supp. $2 d$ at 561 ("In most cases, a domain name registration is valueless apart from the way it is used by the entity with rights to it ....").

179. Id. at 560 n.9, 561 .

180. Id. at 561; see supra Parts IV.A and IV.B (discussing domain names as corporate assets and domain name valuation).

181. See Dorer v. Arel, 60 F. Supp. 2d 558, 561 (E.D. Va. 1999) ("Indeed, there is a lucrative market for certain generic or clever domain names that do not violate a trademark or other right of interest but are otherwise extremely valuable to Internet entrepreneurs."); see also supra Part IV.B and accompanying notes (discussing domain names in secondary market).

182. See David Streitfeld, \$S.com; On the Web, Simplest Names Can Become Priciest Addresses, WASH. POST, July 15, 1999, at A1 (noting that "root names" provide credibility).

183. See Kremen v. Cohen, 99 F. Supp. 2 d 1168, 1173-74 \& n.2 (N.D. Cal. 2000) (refusing to extend tort of conversion to domain names via exception for intangible property represented by documents, but distinguishing Lockheed and Umbro); Network Solutions, Inc. v. Umbro Int'l, Inc., 529 S.E.2d 80, 86 (Va. 2000) (finding that domain names are service contracts and thus not subject to garnishment); see also Panavision Int'l v. Toeppen, 141 F.3d 1316,1325 (9th Cir. 1998) (arbitraging domain names is "commercial use" resulting in trademark infringement); Lockheed Martin Corp. v. Network Solutions, Inc., 985 F. Supp. 949, 958-59 (C.D. Cal. 1997) (finding that domain name registrars do not commit trademark dilution, unfair competition, or trademark infringement in providing their usual services).

184. See Dorer, 60 F. Supp. 2d at 561-62 (avoiding "knotty issue" of characterization by forcing plaintiff to attempt to use registrar's dispute resolution procedure before issuing writ of fieri facias); Network Solutions, Inc., 529 S.E.2d at 86 (claiming that, irrespective of classification, contractual rights do not exist apart from registrar's services, and service contract not subject to garnishment). 
International, Inc. v. 3263851 Canada, Inc. ${ }^{185}$ a Virginia circuit court held that a domain name registration is personal property and, thus, subject to judgment liens and gamishment proceedings. ${ }^{186}$ The judgment creditor in that case, Umbro International, sought to garnish domain names registered by the judgment debtor, 3263851 Canada, with the garnishee, NSI ${ }^{187}$ NSI opposed the gamishment by arguing inter alia that a judgment lien cannot extend to domain names because the rights set forth in domain name registration agreements depend on unperformed conditions, such as the registrar's rights to indemnification and the registrant's continuing obligation to maintain an accurate registration record. ${ }^{188}$ The court rejected this argument because NSI essentially agreed to garnishment under its dispute policy. ${ }^{189}$ Furthermore, the conditions would serve merely to discount the value of the domain names at a sheriff's auction. ${ }^{190}$

The Virginia Supreme Court reversed, reasoning that regardless of how one classifies domain names, they are not garnishable because the right to their use is inextricably bound to the services NSI provides. ${ }^{191}$ Essentially, the judgment debtor's rights over its domain names do not exist independently of NSI's services that make the names operational Internet addresses. ${ }^{192}$ More broadly, the court was concerned that allowing the garnishment of NSI's domain name services would open the door to garnishment

185. 48 Va. Cir. 139 (1999).

186. Umbro Int'l, Inc. v. 3263851 Canada, Inc., 48 Va. Cir. 139, 141-42 (1999), rev'd sub nom., Network Solutions, Inc. v. Umbro Int'l, Inc., 529 S.E. $2 d 80$ (Va. 2000). The circuit court rejected the garnishee-registrar's arguments that the judgment debtor-registrant did not have a possessory interest in the domain names sufficient to support a writ of fieri facias (a lien on the judgment debtor's intangible property) because (1) the contractual rights of the registration agreement depended on unperformed conditions, (2) the lien would force the registrar to perform services for parties with whom it would prefer not to deal, (3) domain names lack a readily ascertainable value, and (4) this form of intellectual property results from a service provided by the registrar and is, therefore, not subject to garnishment. Id. at 14344. The court rejected the fourth argument by analogizing domain names to patents, stating: "the fact that this form of intellectual property results from a service that NSI [the gamishee] provides does not (as NSI argues) preclude the property from garnishment any more than the service provided by the Patent Office in issuing a patent immunizes patents from garnishment." Id. at 144 (citations omitted). However, other courts have criticized this analogy. See Dorer, 60 F. Supp. 2d at 560 n.9 (reasoning that patents, unlike domain names, have intrinsic value regardless of use, and even patents may not be subject to judgment liens under Virginia law).

187. Umbro, 48 Va. Cir. at 139.

188. Id. at 143 .

189. Id.

190. Id.

191. Network Solutions, Inc. v. Umbro Int'l, Inc., 529 S.E.2d 80, 86, 88 (Va. 2000).

192. Id. at 86 . 
of any service. ${ }^{193}$ Thus, the court concluded that "a domain name registration is the product of a contract for services between the registrar and registrant" and, therefore, is not a liability under the Virginia garnishment statutes. ${ }^{194}$

While relying on the above quotation from Dorer v. Arel, ${ }^{195}$ the Umbro court apparently did not grasp the subtlety of the court's reasoning in that case. ${ }^{196}$ In Dorer, the plaintiff sought a writ of fieri facias (or judgment lien) to acquire the defendant's domain name in satisfaction of a trademark infringement judgment. ${ }^{197}$ The court admitted that whether domain names are personal property subject to judgment liens is a "knotty issue" because domain names that are not trademarks arguably entail only contractual rights. ${ }^{198}$ According to the Dorer court, in most instances, a domain name is valueless apart from its method of use by the entity that has rights to it. ${ }^{199}$ Consequently, "if the only value that comes from transfer of the domain name is from the value added by the user, it is inappropriate to consider that an element subject to execution. . $^{1200}$ However, the court also recognized that some domain names are very valuable assets irrespective of any goodwill that might be attached to them. ${ }^{201}$ Because all domain names are freely assignable apart from their content, those that are generic or clever often trade for high prices on the open market. ${ }^{202}$ Such domain names could be attractive targets for judgment creditors. ${ }^{203}$ Because the plaintiff in Dorer did not claim that the domain name at issue had any value on the open market, however, the court's observation was moot. ${ }^{204}$ Furthermore, the Dorer court decided not to resolve the issue of whether a domain name is personal property subject to a judgment lien, believing instead that the self-help measures pursuant to NSI's Domain Name Dispute Policy were more effective and less problematic for the plaintiff than seeking to compel the defendant to transfer the domain name in satisfaction of the judgment. ${ }^{205}$ Thus, the court deferred the writ pending plaintiff's recourse to the self-help method. ${ }^{206}$

193. Id. at 86-87.

194. Id. (quoting Dorer v. Arel, 60 F. Supp. 2d 558, 561 (E.D. Va. 1999)).

195. 60 F. Supp. 2 d 558 (E.D. Va. 1999).

196. Dorer v. Arel, 60 F. Supp. 2d 558, 558-61 (E.D. Va. 1999).

197. Id. at 558-59.

198. Id. at 561 .

199. Id.

200. Id. (citation omitted).

201. Id.

202. Id.

203. Id.

204. Id. at 561 n. 14 .

205. Id. at 561-62.

206. Id. 
The Umbro court also ignored the fact that NSI's domain name registration agreement provides registrants with contractual rights to the exclusive use of their names, amounting to a current possessory interest in their use. ${ }^{207}$ As observed by the two dissenting justices in Umbro, these contractual rights are not conditional, uncertain, or akin to personal services because both parties already have fulfilled their obligations. ${ }^{208}$ For example, in this case, the judgment debtor submitted its registration forms, made certain representations, and paid the registration fees. ${ }^{209}$ NSI completed the registration of the judgment debtor's domain names under NSI's first-come, first-served policy, thus giving the judgment debtor the right to the exclusive use of the domain name for an initial period of two years. ${ }^{210}$ The dissenters concluded:

Because NSI has received everything required to give the judgment debtor the exclusive right to use the domain names it registered, the contractual right, a valuable asset, is the intangible personal property in which the judgment debtor has a possessory interest .... [T] his right exists separate and apart from NSI's various services that make domain names operational Internet addresses. These services... are mere conditions subsequent that do not affect the garnishment analysis. ${ }^{211}$

Like the Dorer court, however, the Umbro court explicitly noted that its holding did not depend on a proper classification of domain names. ${ }^{212}$ The court was concerned more with garnishment of domain names than with the question of whether domain names actually are intangible property. ${ }^{213}$ The court observed that there are "certain types of intangible, intellectual property that have not been subject to levy and sale under execution."214 The court noted that patents, copyrights, and trademarks historically cannot be subject to seizure or sale by means of an execution. ${ }^{215}$ The court stopped its observation

207. Network Solutions, Inc. v. Umbro Int'l, Inc., 529 S.E.2d 80, 89 (Va. 2000) (Compton, S.J., dissenting); see also VeriSign Service Agreement, at http://www.netsol.com/en_US/legal/ service-agreement.jhtml (last visited Oct. 18, 2001) (detailing agreement).

208. Umbro, 529 S.E.2d at 89 (Compton, S.J., dissenting).

209. Id.

210. Id. The registration process with NSI only takes a few minutes to complete. To register a domain name with NSI, see http://www.netsol.com/en_US/ (last visited Oct. 18, 2001).

211. See Umbro, 529 S.E.2d at 89 (Compton, S.J., dissenting).

212. Id. at 86.

213. See id. at 85 (reviewing Virginia garnishment procedures).

214. Id. at $86 \mathrm{n} .13$.

215. Id. The court observed:

Historically, certain types of intangible, intellectual property have not been subject to levy and sale under execution. See Ager v. Murray, 105 U.S. 126, 131, 26 L. Ed. 
there. If the Umbro court furthered its analysis, it would have noted that although patents, copyrights, and trademarks are not subject to levy and sale under execution, they still are classified as intangible property that can be used as collateral to secure payment or obligation in commercial financing. Consequently, domain names - like patents, copyrights, and trademarks - are not subject to levy and sale under execution, but, nevertheless, are a form of intangible property for the purpose of a secured transaction. Because the Umbro court's concern was primarily with the use of domain names in garnishment proceedings, its decision is "superficially appealing" to the issue of correct classification of domain names. ${ }^{216}$

Recognizing the shortcomings in the Umbro decision, a federal district court in the Northern District of Califormia in Kremen v. Cohen ${ }^{217}$ declined to adopt the majority's reasoning in Umbro. ${ }^{218}$ The Kremen court observed that the Umbro decision fails to adequately analyze the issue of the correct classification of domain names. ${ }^{219}$ The Kremen court, instead, found merit in the dissenting position that the right to use domain names "exists separate and apart from NSI's various services that make domain names operational Internet addresses. These services are . . . mere conditions subsequent."220

In Kremen, one of the plaintiff's allegations was that the defendant converted the plaintiff's domain name, "sex.com. ${ }^{1221}$ The Kremen court held that the domain name "sex.com" is intangible property ${ }^{222}$ because it is not

942 (1881) ("debtor's interest in the patent rights ... cannot be taken on execution at law"); Stephens v. Cady, 55 U.S. 528, 531, 14 How. 528, 14 L. Ed. 528 (1852) (copyright "is not the subject of seizure or sale by means of" an execution, but it "may be reached by a creditor's bill"); Stuzman v. C.A. Nash \& Son, Inc., 189 Va. 438, 446, 53 S.E.2d 45, 49 (1949) ("there is no property in a trade-mark" aside from its use in a trade or business). But see McClaskey v. Harbison-Walker Refractories Co., 138 F.2d 493, 500 (3d Cir. 1943) (allowing judgment creditor to reach judgment debtor's patent by using writ of fieri facias).

Network Solutions, Inc. v. Umbro Int'l, Inc., 529 S.E.2d 80, 86 n.13 (Va. 2000).

216. See Kremen v. Cohen, 99 F. Supp. 2d 1168, 1173 (N.D. Cal. 2000) (declining to adopt reasoning of Umbro court).

217. 99 F. Supp. 2d 1168 (N.D. Cal. 2000).

218. Kremen v. Cohen, 99 F. Supp. 2 d 1168, 1168 (N.D. Cal. 2000).

219. Id. at 1173 n.2.

220. Id. (quoting Network Solutions, Inc. v. Umbro Int'l, Inc., 529 S.E.2d 80, 88-89 (Va. 2000) (Compton, S.J., dissenting)).

221. Id. at 1172-73.

222. In a later issued opinion, the Kremen court expanded its previous finding that a domain name is a form of intangible property. The court cited to Yuba River Power Co. $v$. Nevada Imigation Dist., 279 P. 128, 129 (Cal. 1929), for the proposition that property includes "everything which one person can own and transfer to another. It extends to every species of right and interest capable of being enjoyed as such upon which it is practicable to place a money 
merged in or identified with a document or other tangible object. ${ }^{223}$ As intangible property, a domain name cannot serve as a basis for a conversion claim under California law. ${ }^{224}$ Only intangibles represented by documents, such as bonds, notes, bills of exchange, stock certificates, and warehouse receipts, are subject to conversion claims under California law. ${ }^{225}$ California law does not recognize conversion of other intangibles, such as goodwill of a business, trade secrets, a newspaper route, or a customer list. ${ }^{226}$ Because the defendant effectuated the transfer of the plaintiff's domain name through the use of a forged document, the court ordered NSI to restore registration of the "sex.com" domain name to the plaintiff. ${ }^{227}$

In summary, an Internet domain name is not a proper subject of a conversion claim. ${ }^{228}$ The lack of a conversion tort, however, is not uncommon for most intangible property. ${ }^{229}$ Moreover, trademarks are not separate property rights. They are "integral and inseparable elements of the goodwill of the business or services to which they pertain ... [and] . . goodwill is inseparable from the business with which its is associated."230 Thus, trademarks are not chattel and not subject to conversion. Similarly, a trademark registration cannot be bought or sold "in gross" apart from the mark and the goodwill .associated with it. ${ }^{231}$ A registration can be obtained only after the acquisition

value." Kremen v. Cohen, No. C 98-20718JW, 2000 WL 811403, at *3 (N.D. Cal. Nov. 27, 2000).

223. Kremen, 99 F. Supp. 2d at 1173; see also Domain Name Cannot Be Converted, Wash. Fed. Court Rules, 18 No. 3 ANDREws COMPUTER \& ONLINE INDUS. LITIG. REP. 7 (Oct. 24, 2000) (reporting minute order entered by federal district court for Western District of Washington in case entitled Freel.net v. Freel Networks, Inc., No. C00-1101Z ( ), holding domain names are intangible property and, therefore, not subject to conversion tort under Washington law).

224. Kremen, 99 F. Supp. $2 d$ at 1172-73.

225. Id.

226. Id.

227. Kremen v. Cohen, No. C 98-20718JW, 2000 WL 1811403, at*4, *6 (N.D. Cal. Nov. $27,2000)$.

228. See Am. Bankers Mortgage Corp. v. Fed. Home Loan Mortgage Corp., 75 F.3d 1401, 1411 (9th Cir. 1996) (stating elements of conversion claim in California); Kremen v. Cohen, 99 F. Supp. 2d 1168, 1172 (N.D. Cal. 2000) (explaining that Califomia law allows conversion actions for certain intangibles, such as bonds, notes, stock certificates, and warehouse receipts but not for goodwill of business, trade secrets, newspaper routes, or lists of customers); 5 B.E. WITKIN, SUMMARY OF CALIFORNIA LAW, TORTS $\$ 613$ (9th ed. 1988) (explaining that, originally, tort of conversion was confined to tangible property).

229. See Miles Inc. v. Scripps Clinic \& Research Found., 810 F. Supp. 1091, 1096 (S.D. Cal. 1993) ("[]t is not uncommon for a person to have an intangible property right without a cause of action in conversion to protect that right.").

230. VISA, U.S.A., Inc. v. Birmingham Trust Nat'l Bank, 696 F.2d 1371, 1375 (Fed. Cir. 1982).

231. Id. at 1375. 
of ownership by use. ${ }^{232}$ Simply put, trademark registrations and applications are not chattel and, thus, are not subject to conversion tort. ${ }^{233}$

Although domain names are not the proper subject of a conversion tort; they, like other intangible property, can be used as collateral in secured transactions. As discussed in Part III, trademarks and trademark applications are "personal property" that can be used as collateral to secure payment or obligations under Article 9 of the UCC. Moreover, some domain names, unlike trademarks, are valued highly in the open market irrespective of their attending goodwill. These domain names, as noted above, are generic and memorable words and, therefore, are not protected under the Lanham Act. The domain names are valuable even without the attached goodwill, and, thus, they are freely assignable and transferable. ${ }^{234}$ Consequently, domain names should be recognized as intangible property for purposes of secured transactions. ${ }^{235}$

232. See F.R. Lepage Bakery, Inc. v. Roush Bakery Prods. Co., 851 F.2d 351, 353 (Fed. Cir. 1988) (differentiating between collective marks and trademarks), withdrawn 863 F.2d 43 (Fed. Cir. 1988).

233. See id. at 351 (holding that trademark registrations are not chattel); see also VISA, 696 F.2d at 1371 (holding that trademarks "are not separate property rights").

234. Dorer v. Arel, 60 F. Supp. 2d 558, 561 (E.D. Va. 1999).

235. Presently, pursuant to the service agreement between NSI and a registrant, a registrant may transfer domain name registrations to a third party of choice. Network Solutions Service Agreement, ๆ 23, at http:/www.netsol.com/en_US/legal/service-agreement.jhtml (last visited Oct. 26, 2001). NSI, however, forbids registrants assigning their rights under the Agreement, and any attempt by the registrant's creditors to obtain an interest in registrant's rights under the Agreement - whether by attachment, levy, garnishment, or otherwise - renders the Agreement voidable at NSI's discretion. Id. This provision is self-contradictory. On one hand, registrants have the right to transfer (read outright sale for value) domain names, and, on the other hand, they are forbidden to obtain value for their domain names if they decided to use domain names as collateral. The provision seems to serve as an attempt to follow the $U m b r o$ majority decision prohibiting the use of domain names in garnishment proceedings. Such an attempt should be narrowly drafted in order to avoid contradiction.

Further, such an attempt should abide by the Kremen court's determination that although domain names are not property and, therefore, inapplicable subjects of conversion torts, domain names are intangible property and can be transferred. As the Kremen court noted that NSI has asserted repeatedly that domain names are a form of intangible property, NSI should not contradict its assertion by prohibiting a registrant's creditors to obtain an interest in domain names. See Kremen v. Cohen, 99 F. Supp. 2d 1168, 1173 (N.D. Cal. 2000) (explaining that NSI contended that domain names are forms of intangible property); Network Solutions, Inc. v. Umbro Int'l, Inc., 529 S.E.2d 80, 86 (Va. 2000) (noting that NSI acknowledged that right to use domain name is form of intangible personal property). Moreover, $\$ 9-408$ of the UCC will generally render ineffective the transfer and assignment provision. Section $9-408$ explicitly states that an agreement that prohibits or restricts the assignment or transfer of, or creation, attachment, or perfection of a security interest in a general intangible is non-efficacious. U.C.C. § 9408 (2001). See generally Jonathan C. Krisko, Recent Development, UCC Revised Article 9: Can Domain Names Provide Security for New Economy Businesses?, 79 NCLR 1178 (2001) (discussing security interests in domain names); Lois R. Lupica, Revised Article 9, Securitiza- 


\section{Domain Names and the Relevant Federal Statute}

Congress recently passed the Anticybersquatting Consumer Protection Act (ACPA) ${ }^{236}$ which authorizes in rem civil actions against a domain name in the judicial district in which the domain name registrar or registry is located. ${ }^{237}$ Furthermore, a domain name's "situs" for jurisdictional purposes is where "documents sufficient to establish control and authority regarding the disposition of the registration and use of the domain are deposited with the court."1238

By recognizing a domain name as a "thing" for in rem civil actions, the ACPA lends support to the classification of domain names as a form of intangible property. ${ }^{239}$ The ACPA provides that the remedies in these actions are limited to an order for the forfeiture or cancellation of the domain name or the transfer of the domain name to the owner of the trademark. ${ }^{240}$ The ACPA requires the registrar of the domain name to deposit with the court documents sufficient to establish the court's control and authority regarding the disposi-

tion Transactions and the Bankruptcy Dynamic, 9 AM. BANKR. INST. L. REV. 287 (2001) (discussing securitization of intangible assets).

236. The ACPA is codified at 15 U.S.C. \$ 1125(d) (1999). See Anticybersquatting Consumer Protection Act, Pub. L. No. 106-113, $\$ \S 3001-3010$ (1999) (authorizing certain civil actions against domain names); see also Sporty's Farm v. Sportsman's Mkt., Inc., 202 F.3d 489, 495 (2d Cir. 2000) (quoting relevant legislative history on purpose of ACPA); Joel Voelzke, New Cybersquatting Law Gives Trademark Owners Powerful New Weapons Against Domain Name Pirates, 17 No. 2 COMPUTER LAW. 3, 3 (2000) (explaining that ACPA "articulates a strong federal policy against registering or keeping domain names for the main purpose of profiting by selling those domain names to trademark owners or to people whose personal names are similar to the domain name"). See generally Michael S. Denniston \& Margaret Smith Kubiszyn, www.yourclient.com: Choosing Domain Names and Protecting Trademarks on the Internet, 61 ALA. LAW. 40 (Jan. 2000) (outlining basics of Internet domain name trademark protection); Jeremy D. Mishkin, Master of Your Domain - An Overview of the Anticybersquatting Consumer Protection Act 18-SPO COMM. LAW 3 (2000) (discussing courts' previous treatment of intellectual property disputes regarding domain names and new regime of ACPA).

237. See 15 U.S.C. \& 1125(d)(2)(C)(ii) (1999) (stating that in rem suit can be brought in judicial district where registrar is located or where "documents sufficient to establish control and authority regarding the disposition of the registration and use of the domain are deposited with the court").

238. Id.

239. See Chertok \& Agin, supra note 17, at 275 (observing that ACPA recognizes domain names as intangible property for purposes of barring use of domain names, but fails to characterize domain names as assets that may be subjects of judicial liens).

240. 15 U.S.C. \&1125(d)(2)(D)(i) (1999). Procedurally, the trademark owner must deliver a file stamped copy of the complaint to the registrar. The registrar then freezes the domain name, except to transfer or cancel as ordered by the court. The registrar also must deposit the domain name with the court. The court can grant only injunctive relief in the form of a forfeiture, cancellation, or transfer of the domain name. 
tion of the registration and use of the domain name. ${ }^{241}$ The ACPA, as some courts have observed, treats domain names as property or as having propertylike attributes. ${ }^{242}$

For example, in Caesars World, Inc. v. Caesars-Palace.Com ${ }^{243}$ the plaintiff brought an in rem action against several domain names under the ACPA. ${ }^{244}$ The defendants moved for dismissal of the complaint for lack of in rem jurisdiction, arguing that domain names are not proper "things" to serve as "res"; they are merely data that form part of Internet addresses and thus are not property. ${ }^{245}$ The court rejected the defendants' argument and held that "[t]here is no prohibition on a legislative body making something property. Even if a domain name is no more than data, Congress can make data property and assign its place of registration as its situs. ${ }^{1246}$ Indeed, courts routinely treat domain names as property by ordering registrants to retum domain names to trademark owners. ${ }^{247}$

The ACPA does not provide any guidance as to the assignment or transfer of ownership in domain names or as to security interests in domain names because Congress passed the Act solely for the purpose of eliminating Act recognizes domain names as "things" for the purpose of in rem jurisdiction, it implicitly recognizes that domain names have become valuable commodities in e-commerce. ${ }^{248}$ Undeniably, there are property interests in

241. Id.

242. See Caesars World, Inc. v. Caesars-Palace.Com, 112 F. Supp. 2d 502, 504 (E.D. Va. 2000) (treating domain names as property for purpose of in rem jurisdiction); see also Virtual Works, Inc. v. Volkswagen of Am., Inc., 238 F.3d 264, 271 (4th Cir. 2001) (affirming district court's order to registrant Virtual Works to tum over "vw.net" to Volkswagen).

243. 112 F. Supp. 2d 502 (E.D. Va. 2000).

244. Caesars World, Inc. v. Cacsars-Palace.Com, 112 F. Supp. 2d 502, 502 (E.D. Va. 2000).

245. See id. at 504 (explaining defendant's argument).

246. Id. at 504.

247. See Virtual Works, Inc., 238 F.3d at 271 (affirming district court's order to registrant Virtual Works to turn over "vw.net" to Volkswagen); Ford Motor Co. v. Lapertosa, 126 F. Supp. 2d 463, 468 (S.D. Mich. 2001) (ordering defendant to transfer fordrecalls.com to plaintiff); Simon Property Group, L.P. v. mySimon, Inc., No. IP 99-1195-CH/G, 2001 WL 66408, at 20 (S.D. Ind. Jan. 24, 2001) (ordering defendant to transfer ownership and registration of www.mysimon.com domain name and any other domain names owned by mySimon, Inc., to plaintiff); Paccar, Inc. v. Telescan Technologies, L.L.C., 115 F. Supp. 2d 772, 780-81 (E.D. Mich. 2000) (ordering defendant to transfer registration and ownership of several domain names to plaintiff); Elecs. Boutique Holdings Corp. v. Zuccarini, No. Civ. A. 00-4055, 2000 WL 1622760, at $* 9$ (E.D. Penn. Oct. 30, 2000) (ordering defendant to transfer group of domain names to plaintiff).

248. See Sporty's Farm v. Sportsman's Mkt., Inc., 202 F.3d 489, 498 (2d Cir. 2000) (making reference to H.R. Rep. No. 106-412 (1999) at 5-7 (1999), S. Rep. No. 106-140, at 4-7 
domain names. ${ }^{249}$

\section{Securing Interest in Domain Names}

\section{A. Perfection Through Filing with the State}

Section 9-310 of revised Article 9 of the UCC states that perfection of security interests in collateral that do not fall within the enumerated exceptions in the provision ${ }^{250}$ is achieved through filing a financing statement with

(1999), and noting that purpose of ACPA is to stop cybersquatting conduct of demanding ransom money from trademark owners to get their domain names back).

249. Other experts have recognized that although domain names are not property for the tort of conversion, there are property interests in generic domain names. Professor Pamela Samuelson has commented on the Kremen v. Cohen decision regarding the domain name "sex. com": "[T]he Sex.com name is so commercially valuable that the notion it's not property seems kind of crazy. But I'd be reluctant to say there's a property right in generic domain names under existing law. Courts are usually careful to avoid judicially legislating something this important." John Roemer, Web Domain Name Not Protected by Property Laws, U.S. Judge Rules, INDUSTRY STANDARD (Dec. 15, 2000). Consequently, "it would seem preferable to fashion other remedies, such as unfair competition, to protect people from having intangible values used and appropriated in unfair ways." Kremen v. Cohen, 99 F. Supp. 2d 1168, 1174 (N.D. Cal. 2000) (quoting W. PAGR KeETONET AL.,PROSSER \& KRETONON THE LAW OF TORTS $\$ 15$, at 92 (5th ed. 1984)).

On the other hand, other experts believe that "elements of domain names are more similar to real estate than to trademarks, and therefore, it would be economically efficient to grant domain name owners stronger rights than those of mere trademark holders." Kenton K. Yee, Location.Location.Location: Internet Addresses as Evolving Property, 6 S. CAL. INTERDISCIPLINARY L.J. 201, 201 (1997); see also Carl Oppendahl, Remedies in Domain Name Lawsuits: How Is a Domain Name Like a Cow?, 15 J. MARshaLl J. COMPUTER \& INFO. L. 437, 442-44 (1997) (suggesting domain name is property based on fact that domain names are capable of being bought and sold).

250. The 2001 version of $\$ 9-310($ b) states that the filing of a financing statement is not necessary to perfect a security interest in collateral:

(1) that is perfected under Section 9-308(d), (e), (f), or (g);

(2) that is perfected under Section 9-309 when it attaches;

(3) in property subject to a statute, regulation, or treaty described in Section 9. 311(a);

(4) in goods in possession of a bailee which is perfected under Section 9$312(d)(1)$ or $(2)$;

(5) or in certificated securities, documents, goods, or instruments which is perfected without filing or possession under Section 9-312(e), (f), or (g);

(6) in collateral in the secured party's possession under Section 9-313;

(7) in a certificated security which perfected by delivery of the security certificate to the secured party under Section 9-313;

(8) in deposit accounts, electronic chattel paper, investment property, or letterof-credit rights which is perfected by control under Section 9-314;

(9) in proceeds which is perfected under Section 9.315; or 
a state office. ${ }^{251}$ In most states, the appropriate filing office is the office of the secretary of state ${ }^{252}$ Accordingly, the filing of a financing statement indicating the domain names as collateral with that office will ensure perfection of the security interests in the domain names. ${ }^{253}$ Consequently, this raises a question as to the state with which the secured party should file the financing statement and which jurisdiction's choice of law will govem perfection rules and effects of perfection. Revised section 9-301 provides that the law governing perfection of non-possessory security interests in intangible collateral, whether perfected by filing or automatically, is the law of the jurisdiction of the debtor's location. ${ }^{254}$

In scenarios in which the debtor is located in one state and the collateral, such as goods, documents, instruments, money, negotiable documents, and tangible chattel paper as indicated in section 9-301(3), is located in a different state, Article 9 has new multi-state rules. ${ }^{255}$ Under the new multi-state rules, the state in which the debtor is located controls as to the place of perfection; the state in which the collateral is located controls as to the rules of perfection

(10) that is perfected under Section 9-316.

U.C.C. $\S 9.310(b)(2001)$.

251. U.C.C. $\$ 9-310$ (a) states, "Except as otherwise provided in subsection (b) and Section \$ 9-312(b), a financing statement must be filed to perfect all security interests and agricultural liens." U.C.C. \$ 9-310(a) (2001).

252. See U.C.C. $\$ 9-501$ (2001) (encouraging central filing for all collateral that is not timber to be cut, minerals to be extracted, or fixtures).

253. See U.C.C. \& 9-310 (2001) (setting guidelines for filing for perfection of security interests). The author recognizes that in recent years, with the growth in e-commerce, many trademarks have been used as domain names. In such instances, the domain names are still trademarks and; thus, enjoy all the protection provided under Lanham Act. Further, perfection of security interests in domain names that are trademarks follows the similar scheme for perfection of security interests in trademarks.

254. Revised \$ 9-301 states in pertinent part:

[T] $T$ he following rules determine the law governing perfection, the effect of perfection or nonperfection, and the priority of a security interest in collateral:

Except as otherwise provided in this section, while a debtor is located in a jurisdiction, the local law of that jurisdiction governs perfection, the effect of perfection or nonperfection, and the priority of a security interest in collateral.

U.C.C. \$ 9-301 (2001). Official Comment 4 to section 9-301 states that "the law governing perfection of security interests in both tangible and intangible collateral, whether perfected by filing or automatically, is the law of the jurisdiction of the debtor's location." U.C.C. \$ 9.301 cmt. 4 (2001). "The general rule is subject to several exceptions . . . . Nor does it apply to possessory security interests, i.e., security interests that the secured party has perfected by taking possession of the collateral ...." U.C.C. \& 9-301 cmt. 5 (2001).

255. See U.C.C. \& 9-301 \& cmt. 7 (2001) (providing that law of jurisdiction in which collateral is located governs priority). 
and priority. ${ }^{256}$ For example, if the debtor is located in Nevada and the collateral is located in California, Nevada law will dictate which office, the office of the secretary of state or the office of the county clerk, is the appropriate place for the creditor to file the financing statement. ${ }^{257}$ California law will govern the rules of perfection and priority. In other words, California law will dictate how perfection in such collateral can be achieved, whether through automatic perfection at the time of attachment of the security interests in the collateral, through the filing of a financing statement, or through possession of the collateral, and how the rights of competing claimants to tangible collateral are resolved. ${ }^{258}$

The above choice of law rule, however, only applies to goods, documents, instruments, money, negotiable documents, and tangible chattel paper. ${ }^{259} \mathrm{Be}-$ cause domain names are not the type of collateral covered under the rule, regardless of where domain names are "located," the law governing perfection of security interests in domain names and effects of perfection or nonperfection is the law of the jurisdiction of the debtor's location. ${ }^{260}$

The debtor's location is determined by revised section 9-307. This section states that if the debtor is an individual, the debtor's location is the individ-

256. U.C.C. \& 9-301 cmt. 7 (2001). Comment 7 states:

Under former Section \& 9-103, the law of a single jurisdiction governed both questions of perfection and those of priority. This Article generally adopts that approach. But the approach may create problems if the debtor and collateral are located in different jurisdictions. For example, assume a security interest in equipment located in Pennsylvania is perfected by filing in Illinois, where the debtor is located. If the law of the jurisdiction in which the debtor is located were to govern priority, then the priority of an execution lien on goods located in Pennsylvania would be governed by rules enacted by the Illinois Legislature.

To address this problem, paragraph $(3)(C)$ divorces questions of perfection from questions of "the effect of perfection or nonperfection and the priority of a security interest." Under paragraph (3)(C), the rights of competing claimants to tangible collateral are resolved by reference to the law of the jurisdiction in which the collateral is located.

U.C.C. $\$ 9-301 \mathrm{cmt} .7$ (2001).

257. Id.

258. Id.

259. Id. Domain names are general intangibles which are defined as "any personal property, including things in action, other than ... goods ..." U.C.C. \& 9-102(42) (2001). The state of the debtor's location governs the security interest in general intangibles that is perfected. See Steven O. Weise, PEB Report: Article 9 Perfection Choice of Law Analysis Where Revised Article 91s Not in Effect in All States by July 1, 2001, 56 Bus. LAw. 1725, 1732 (2001) (discussing choice of law rules under revised Article 9 and former Article 9).

260. Because domain names are not the type of collateral covered under section 9-301(3) as explained by the Official Comment 7, section 9-301(1) of the 2001 code will govern the choice of law. 
ual's principal residence..$^{261}$ If the debtor is an organization and has only one place of business, the debtor's location is its place of business, ${ }^{262}$ and if the debtor is an organization and has multiple places of business, the debtor's location is at its chief executive office. ${ }^{263}$ Further, if a debtor is a registered organization, the state that registered the organization is deemed as the place at which the debtor is located. ${ }^{264}$. Accordingly, if the debtor is organized in Califormia, has its headquarters in San Francisco and its branch offices in Ohio, Texas, and New York, the debtor's location is in San Francisco. Consequently, if the debtor pledges domain names as collateral in secured transactions, regardless of where the domain names are "located," California law will govern perfection and priority.

Under the above analysis, a creditor will perfect its security interests in a domain name by filing a financing statement with a state office in the state in which the debtor is deemed located. ${ }^{265}$ The creditor, however, prior to conducting such filing, needs to verify whether the debtor is indeed the owner of the domain name as part of due diligence. 266 . This requires the creditor to conduct a search with the WHOIS database. ${ }^{267}$ Upon such verification, if, indeed the debtor is the owner of the domain name, the creditor may then

261. U.C.C. $\$ 9-307(b)(1)$ (2001) ("A debtor who is an individual is located at the individual's principal residence.").

262. U.C.C. $\$ 9-307$ (b)(2) (2001) ("A debtor that is an organization and has only one place of business is located at its place of business.").

263. U.C.C. \$ 9-307(b)(3) (2001) ("A debtor that is an organization and has more than one place of business is located at its chief executive office.").

264. U.C.C. \& 9-307(c) (2001) ("A registered organization that is organized under the law of a State is located in that State.").

265. Cf. Delaware v. New York, 507 U.S. 490, 503 (1993) (noting common law rule that intangible personal property is found at domicile of owner).

266. Moreover, under Article 9, perfection of security interests does not occur unless such interests are attached against the debtor and other creditors. As a condition for attachment, the debtor must have rights in the domain name collateral. See U.C.C. \$9-203(b)(2) (2001) (stating that security interest is enforceable against debtor and third parties if "debtor has rights in the collateral").

267. Pursuant to the Registrar Accreditation Agreement between a registrar and ICANN, a registrar must provide free public access to an on-line, interactive WHOIS database that contains the names and contact information such as postal address, telephone number, electronic mail address, and facsimile number, if available. See Register.com, Inc. v. Verio, Inc., $126 \mathrm{~F}$. Supp. 2d 238, $241-42$ (S.D.N.Y. 2000) (explaining operation of WHOIS database). The public can "collect registrant contact information for one domain name at a time by entering the domain name into the provided search engine." Id. at 242 . Individuals or entities that would like to gain bulk access to the WHOIS database on a weekly basis must pay $\$ 10,000$ yearly for the license fee. Id. The primary purpose of the WHOIS database is to "provide necessary information in the event of domain name disputes." Id. at 242. 
proceed with the filing of the financing statement indicating that the domain name is being used as collateral. ${ }^{268}$

This approach is inefficient because it requires the creditor to verify the ownership of the collateral in one place (the WHOIS database) and to file the financing statement covering the domain name at a different place (the office of the secretary of the state in which the debtor is deemed located). Further, it does not give notice to third parties who are accustomed to relying on the WHOIS database for information relating to domain names, to determine if the domain names have been encumbered.

\section{B. Perfection Through Filing with the Registrar of Domain Names}

The purpose of perfection is to provide notice to third parties that the collateral at issue has been encumbered. ${ }^{269}$ To fulfill that purpose, an efficient approach to perfection would be a central filing for all security interests in domain names. Thus, all security interests in domain names would be recorded in the WHOIS database. This system would provide any party who is interested in a domain name easy access to all information regarding the domain names. Most importantly, interested parties could conduct the search electronically at any computer terminal with Intemet access. ${ }^{270}$

Currently, the WHOIS database provides information about domain names' registrants such as a registrant's identity, address, e-mail address, and phone number. ${ }^{271}$ Adding the security interest information of particular domain names into the WHOIS database would provide a "one-stop" service to the public. ${ }^{272}$ Interested parties would not have to conduct two searches at the office of the secretary of state and the WHOIS database.

268. See U.C.C. $\$ 9-310 \mathrm{cmt} .2$ (2001) (stating that filing provision "establishes a central Article 9 principle: Filing a financing statement is necessary for perfection of security interests ....").

269. See U.C.C. $\$ 9-308 \mathrm{cmt} .2$ (2001) ("[A]fter perfection the secured party is protected against creditors and transferees of the debtor and, in particular, against any representative of creditors in insolvency proceedings instituted by or against the debtor.").

270. See Ronald J. Mann, Secured Credit and Software Financing, 85 CORNELL L. REV. 134, 185 (1999) (recognizing third-party cost to discover secured interests on software and suggesting that "[c]urrent technology should make it easy to design a filing system in which the cost of filing would be quite low and in which competing creditors could discover the software lender's interest easily, quickly, and without undue expense").

271. Register.com, Inc., 126 F. Supp. $2 \mathrm{~d}$ at 242.

272. This is consistent with the primary purpose of the WHOIS database - providing necessary information in the event of domain name disputes. See id. (explaining that purpose of WHOIS database is to catalogue domain name ownership in event of dispute). 
Moreover, some interested parties may not know that they need to conduct a search at the office of the secretary of state to ascertain whether a domain name is free and clear from any security interest. They may not know that they must obtain information about the debtor's location to conduct the search in the appropriate state. Even sophisticated companies with the assistance of legal counsel may encounter similar problems, given the fact that Article 9 of the UCC is silent about domain names in the definitions of various types of collateral, including the classification of domain names as general intangibles. ${ }^{273}$ Further, no court has had an opportunity to address the issue of perfection of security interests in domain names. Moreover, the ACPA, the only federal statute pertaining to domain names, falls short of providing a means of using domain names to secure payment or obligation incurred by Internet companies. ${ }^{274}$

The ACPA treats domain names as "things" for in rem civil actions and authorizes courts to seize domain names by forcing the registrar of the domain name to "deposit with the court documents sufficient to establish the court's control and authority regarding the disposition of the registration and use of the domain name. ${ }^{1275}$ Courts, in several cases concerning in rem jurisdiction, have held that domain names are property as legislated by Congress through the ACPA. ${ }^{276}$ Consequently, the ACPA should be amended to provide a national, electronic filing scheme for security interests in domain names. ${ }^{277}$ The

273. See U.C.C. \$ 9-102(42) \& cmt. 5d (2001) (defining general intangible category and providing examples).

274. See supra notes 248-49 and accompanying text (discussing nature of domain name for purposes of determining property interests).

275. 15 U.S.C. \& 1125(d)(2)(D)(i) (1999) provides in pertinent part:

The remedies in an in rem action under this paragraph shall be limited to a court order for the forfeiture or cancellation of the domain name or the transfer of the domain name to the owner of the mark. [U]pon receipt of written notification of a filed, stamped copy of a complaint filed by the owner of a mark in a United States district court under this paragraph, the domain name registrar, domain name registry, or other domain name authority shall -

(I) expeditiously deposit with the court documents sufficient to establish the court's control and authority regarding the disposition of the registration and use of the domain name to the court, and

(II) not transfer, suspend, or otherwise modify the domain name during the pendency of the action, except upon order of the court.

15 U.S.C. $\$ 1125(d)(2)(D)(i)(1999)$.

276. See, e.g., Caesars World, Inc. v. Caesars-Palace.Com, 112 F. Supp. $2 d$ 502, 505 (E.D. Va. 2000) (holding that assertion of in rem jurisdiction does not violate due process rights of domain name owners).

277. The proposed amendment will preempt state regulations regarding perfection of security interests in domain names. See U.C.C. \$9-311 \& cmt. 2 (2001) (explaining filing requirements). 
amendment should be drafted clearly to avoid the ambiguity of the federal statutes governing trademarks. ${ }^{278}$ Such an amendment will preempt the filing provisions of Article 9 of the UCC as stated in sections 9-109 and 9-311. ${ }^{279}$ Because all other information about domain names is currently in the WHOIS database, the recording of security interests in domain names should be included in the WHOIS database to reduce transaction costs and increase search efficiency. The filing of the security interest in a domain name should be recorded with the registrar that registered the domain name. The filing should be done electronically to increase efficiency and minimize paper-based resources.

Further, this amendment to the ACPA would be a strong indication that Congress recognizes the reality of the commercialization of domain names. The amendment would give credence to the fact that domain names are treated as corporate assets and would encourage the use of domain names along with other intellectual property as collateral in commercial financing. ${ }^{280}$

However, the approach is not without shortcomings. First, it may create a monopolistic registrar out of NSI. NSI has been accused of monopolistic behavior, ${ }^{281}$ and although it is no longer the only registrar of domain names, ${ }^{282}$ the company registered virtually all existing domain names in the ".com" Top Level Domains through its original exclusive contract of registration with the government. ${ }^{283}$ Because most, if not all, Internet companies have their domain names in the ".com" Top Level Domain, their creditors or lenders under this proposed system would have to record their security interests in domain names with NSI - the registrar that registered the domain names at issue. To minimize monopolistic behavior, other registrars must be allowed to record

278. See supra notes 76-90 (interpreting Lanham Act trademark assignment provision).

279. See supra notes 56-58 (analyzing revised \$ 9-109 and \$ 9-311).

280. See Chertok \& Agin, supra note 17, at 276-80 (criticizing existing case law as espoused by Virginia Supreme Court in Umbro for thwarting collection efforts of creditors seeking to recover money judgments and relegating these creditors to status of unsecured creditors in event of bankruptcy proceeding).

281. See Name.space, Inc. v. Network Solutions, Inc., 202 F.3d 573, 582 (2d Cir. 2000) (holding that NSI is entitled to implied conduct-based immunity with respect to its refusal to add new gTLDs to root zone file in case in which plaintiff contested NSI's control of master root zone server and file).

282. See id. at 577 ("NSI currently maintains the master root zone server, and was the sole registrar for new domain names under the .com, org, net, edu and .gov gTLDs."); Register.com v. Verio, Inc., 126 F. Supp. 2d 238, 242 n.1 (S.D.N.Y. 2000) (explaining that NSI's core business is maintenance of top-level domain names, servers, and zone files).

283. See Name.space, 202 F.3d at 577-79 (noting that NSI was sole registrar from 1993 through September 30, 2000, pursuant to Cooperative Agreement No. NCR-9218742 and its Amendment No. 11). 
security interests in domain names. ${ }^{284}$ They simply would record electronically the security interests in the "file" in the WHOIS database that contains information about the domain name that would serve as collateral. ${ }^{285}$

Second, this approach will take away the fees associated with the filing of the financing statements currently collected by state offices. ${ }^{286}$ The volume of the existing ${ }^{287}$ and future domain names, if they are used as collateral in secured transactions, ensures handsome fees for the state where the debtor is deemed located. States may not want to relinquish this revenue stream.

\section{Conclusion}

Domain names have become valuable corporate cyberassets. The use of domain names in asset-backed securitization will become common practice in corporate financing schemes. To facilitate such securitization, perfection of security interests in domain names should be a simple process. An electronic, national filing scheme for perfection of security interests in domain names will provide notice to all third parties, reduce the transaction costs, and increase efficiency.

Your VC client is waiting for your answers. You could take an easy way out by informing the client that courts have not addressed the question of

284. See Register.com, 126 F. Supp. 2d at 241 (noting that there are more than fifty registrars for domain names in .com, .net, and .org Top Level Domaing).

285. With the advance of technology, it is possible to include domain name security interest information in the WHOIS database. See Name.space, 202 F.3d at 579 (noting that ICANN and Commerce Department entered into Memorandum of Understanding agreeing to collaborate on "written technical procedures for operation of the primary root server including procedures that permit modifications, additions or deletions to the root zone file").

286. Which entities will collect fees is a potentially sticky issue. The drafters of the revised Article 9 were aware of this and left it to the legislators of each state to determine which office will receive the financing statement filings and the associated fees. See U.C.C. $\$ 9-501$ (2001) (leaving filing office blank for state to supply missing information). It is hard to imagine that state governments will give up easily the potential fees to be collected from securitization of domain names.

Moreover, under the current domain name registration system, thirty percent of domain name registration fees collected by registrars go into an "Intellectual Infrastructure Fund" for future government use on Internet projects. Registrars have protested the thirty percent payment as an unconstitutional tax. Thomas et al. v. Network Solutions, Inc. \& Nat'l Sci. Found., No. 97-2412 TFH, 1998 WL 1738180, at *2 (D.D.C. Aug. 28, 1998). Whether the fees associated with the filing of financing statements should be included in the calculation of domain name registration fees, of which thirty percent will go to the Intellectual Infrastructure Fund, remains for future debates.

287. Currently, there are about 20,000 domain names registered daily. A search conducted on http:/whois.net/ on March 2, 2001 showed 30,173,143 domain names registered. Five days later, on March 7, 2001, the number of registered domain names reached 30,285,017. 
whether domain names are intangible property for secured transaction purposes and how security interests in domain names should be perfected. If domain names are intangible property and Article 9 is the governing law, the client has failed to perfect its security interests in the domain name collateral. As an unsecured creditor, your client's chances of recovering the domain name or the proceeds therefrom are very slim.

Or, you could attempt to explain to your client the archaic language of Article 9, the classification of domain names, and federal preemption of perfection schemes. Federal preemption will occur only if Congress amends the ACPA to provide a national, central, electronic filing of relevant documents to indicate existing security interests in domain names. This system should operate within the WHOIS database; it would make it easier for your client not to lose its interests to the bankruptcy trustee. 